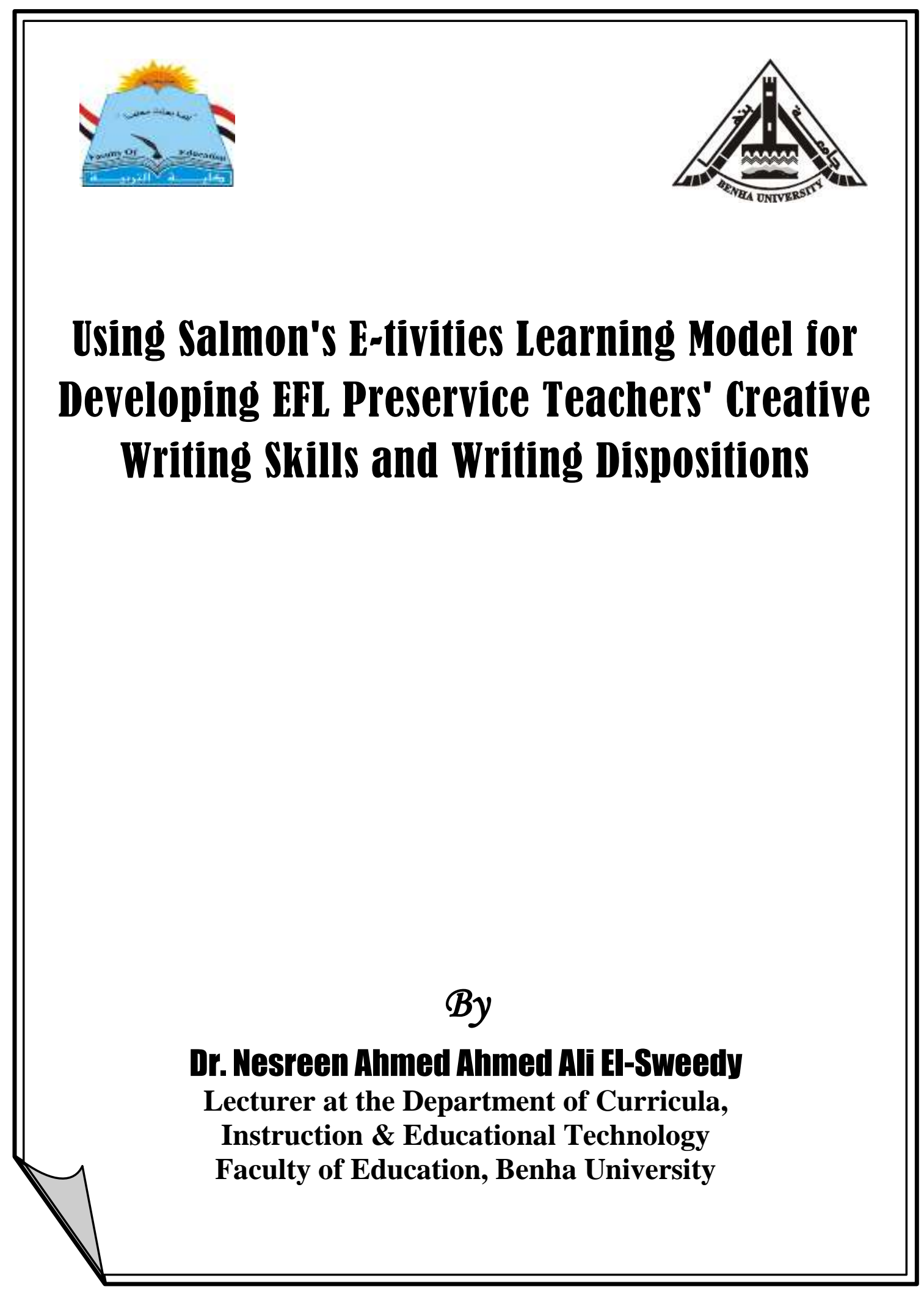




\section{Using Salmon's E-tivities Learning Model for Developing EFL Preservice Teachers' Creative Writing Skills and Writing Dispositions}

By

\section{Dr. Nesreen Ahmed Ahmed Ali El-Sweedy}

Lecturer of EFL,

Department of Curricula,

Instruction \& Educational Technology

Faculty of Education, Benha University

\section{Abstract}

The present study aimed at developing EFL creative writing skills, as simplified in short stories, and writing dispositions using Salmon's Etivities model of online learning. About 96 participants from fourth-year preservice teachers enrolled in the English Section at the Faculty of Education, Benha University were randomly assigned into two groups: an experimental group [ $\mathrm{N}=48]$ and a control group [ $\mathrm{N}=48]$. The present study adopted the mixed research method for data collection and analysis and the pre-post-test control-group design for the intervention. Two main instruments were used for the quantitative analysis: the EFL creative writing pre-posttest with a scoring rubric and the writing disposition scale. Several tools were used to adhere to the qualitative analysis. Results showed that e-tivities learning model was effective in developing EFL creative writing skills and writing dispositions, and that writing disposition can be used as predicators for EFL creative writing skills. It was recommended that this model should be integrated into writing instruction programs.

Key words:EFL creative writing, online learning, e-tivities, Salmon' learning model, writing dispositions 
استفدام نموذج "سالمون" (Salmon) للتعلم القائم علي الأنشطة

الإلكترونية لتنمية مهارات الكتابة الإباعية ونزعات الكتابة

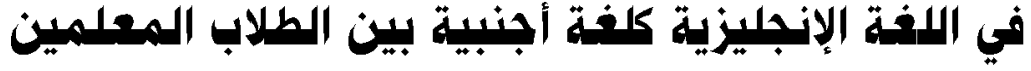

$$
\text { ! }
$$

ه//نسرين أحمد أحمد علي السويدي

مدرس المناهجوطرق تلدريس اللفة الإنجليزية

كلية التربية- جامعة بنها

\section{المستخلــص باللغــة العربيسة}

تهدف الدراسـة الحاليـة إلى تتميـة مهارات الكتابة الإبداعية ونزعات الكتابة في اللغـة الإنجليزية كلغة أجنبية باستخدام نموذج "سالمون" للتعلم القائم علي الأنثطة الإككترونية. وقد تم تقسيم 97 طالباً بالفرقة الرابعة بقسم اللغة الإنجليزية بكلية التربية، جامعة بنها بشكل عشوائي

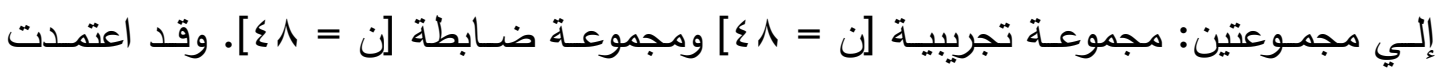
الدراسة علي طريقة البحث المختلط لجمع وتحليل البيانات وعلي تصميم المجموعة التجريبية قياس قبلي وبعدي في التجريب. وتم استخدام أداتين رئيسيتين للتحليل الكمي، وهما اختبارالكتابة الإبداعية في اللغة الإنجليزية كلغة أجنبية مع مقياس تصحيح له، و مقياس نزعات الكتابة. كما

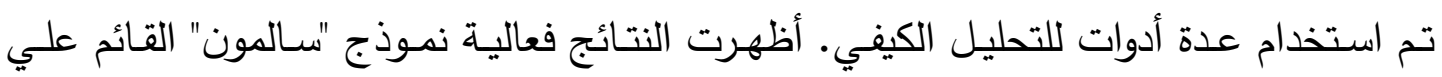
الأنثطة الإكترونية (e-tivities) في تنمية مهارات الكتابة الإبداعية ونزعات الكتابة. وأن نزعات الكتابة يمكن التنبؤ من خلالها بمهارات الكتابة الإبداعية الإبداعية في اللغة الإنجليزية كلغة أجنبية. وأوصت الدراسة بدمج هذا النموذج في برامج تعليم الكتابة. الكلمـات المفتاحيـة :الكتابة الإبداعية - نزعات الكتابة - التعلم الإلكتروني- نموذج سـالمون للتعلم القائم علي الأنثطة الإكترونية. 


\section{Introduction}

In the $21^{\text {st }}$ century, creativity has undeniable importance and is the driving force for sustainably economic, social and political development for the future. However, it is relatively infrequently studied and it seems to be one of the least understood areas of research (Hassan, Edris \& Amer, 2018; Suárez, 2015), particularly when it is interwoven with writing skills. Writing in a foreign language has a main purpose of communicating messages and exploring thoughts and ideas to make them accessible and evident.All EFL writing carries the seeds of creativity (Casey-Williams, 2013).

In the realm of English as a foreign language, writing has distinguished itself into different types to discourage the transfer of skills from type to the other. Therefore, distinctions were made between creative writing, functional writing and expository writing. However, these types are put into greater collaboration to mutually reinforce literate practices while keeping their disciplinary identities separate (Ali, Seleim \& Mohammed, 2016, 2019; Casey-Williams, 2013). In the academic world, creative writing is often considered to have a separate, legitimate, full-fledged and almost privileged position and entity (Clark, 2018; Daniels, 2012). Moreover, in the last two decades, creative writing research has increased in theoretical and/or methodological complexity and explored its relationship with other variables (Mullineaux, 2017). The present study is an attempt to explore how to develop EFL creative writing and writing dispositions and investigate the relationship between them.

\section{Review of literature}

The main distinction between composition and creative writing centers on the specific aims for their end-products. While composition presents more specific expectations for students' end products, the creative writing allows broader possibilities and encourages more idiosyncratic and open-ended goals. It aims to produce texts that meet 
certain criteria, but these criteria tend to be less definite and not directed toward a preconceived writing product (Casey-Williams, 2013).

Historically, creative writing can be defined from two different perspectives. The first one perceives creative writing as the potential to produce the original, novel, useful or adaptive product of an individual. Therefore, it is all about originality-novelty, value-usefulness and adaption to reality (Barbota, Tana, Randib, Santa-Donatoc \& Grigorenkoa, 2012; Clark, 2018; Tung, 2015). The second perspective perceives creative writing as the writer's ability to express his own thoughts, ideas, emotions and feelings in a deep, aesthetic, imaginative and unique way. Accordingly, creative writing is characterized by being original, internally consistent, coherent and plausible (Al-Amro, 2012; Al-Hadi, 2008; Daniels, 2012; Ali, et al., 2016, 2019; Hassan, et al., 2018; Khater, 2015; Mohamed, 2013; Mohammed, Abd-Alhack \& Okasha, 2011; Suárez, 2015).In spite of these two perspectives, it seems that there is certainly neither a universally accepted definition nor a consensus regarding the nature of creative writing (Clark, 2018; Greenlee, 2000; Thaker, 1995).

Compared to the characteristics of the expository writing, Maley (2012) mentions the main characteristics of creative writing (Table 1).

Table 1

Creative writing vs. expository writing (adopted from Maley, 2012, p. 2).

\begin{tabular}{|c|c|}
\hline Expository writing & Creative writing \\
\hline \hline Instrumental & Aesthetic \\
\hline Facts & Imagination \\
\hline external control & internal discipline \\
\hline Conventions & stretching rules \\
\hline Logical & Intuitive \\
\hline Analytical & Associative \\
\hline Impersonal & Personal \\
\hline Thinking & feeling mode (plus thinking) \\
\hline appeal to the intellect & appeal to sense \\
\hline avoidance of ambiguity & creation of multiple meanings \\
\hline \hline
\end{tabular}


Although creative writing is considered to be personal, it has its form and structure (Al-sayed, Ali, Abdel-Haq \& EL-Deeb, 2017; Clark, 2018). Thaker (1995) asserts that creative writing has four features: novelty, value, transgeneration and condensation. "Studies tend to regard the creative writing process as a capricious, idiosyncratic, emotional, talent-driven and less cognitively demanding rhapsody of inspiration compared with the ratiocination of argumentative or persuasive writing composition"(Zhao, 2011, p.19).

By introducing the element of creativity into writing classrooms, students can manipulate the language in interesting and novel ways. They spill out their souls through expressing uniquely personal meanings, thoughts, feelings, ideas and pans without any pressure or fear of being judged and criticized (Akkaya, 2014; Ali, 2018, 2019; Clark, 2018; Khater, 2015; Mohamed, 2013). Creative writing practice improves different language proficiencies:reading, writing, grammar, vocabulary, spelling, phonology and discourse skills (Al Hadi, 2008; Carrier, 2015; Harper, 2015;Mullineaux, 2017; Ramet, 2007).

Creative writing practice provides manifold opportunities for discovering the ontology of writing, its functions and value (Barbota, et al., 2012; Carrier, 2015). Accordingly, it fosters greater motivation and engagement with writing (Khater, 2015). It also teaches students to produce complex affective states in an audience through the use of metaphorical language and sensory images that arouse readers' curiosity and imagination (Carrier, 2015; Khater, 2015; Mohamed, 2013).

Creative writing encourages students' thinking, imagination, persuasiveness in associative, metaphorical, non-linear and nonhierarchical ways (Ahmed, 2016; Carrier,2015; Girardi, 2014; Morris \& Sharplin, 2013). It changes the learning atmosphere into a pleasant, supportive and guilt-free one (Mohammed, et al., 2011). Therefore, it helps students understand their own particular raison d'etre and their writerly identity (Barber, 2004; Carrier, 2015; Mullineaux, 2017). 
Moreover, it enhances students' psychological relief by enabling them dispel their frustrations and any detrimental or problematic thoughts and behaviours by engaging them in artistic activities that keep them detached (Akkaya, 2014; Barber, 2004; Rombough, 2016; Mohamed, 2013). This in turn boasts their self-esteem and confidence (Al-Hadi, 2008; Khater, 2015; Mohamed, 2013; Shalaby, 2015), and in the long run cultivate imaginative, compassionate and informed citizens (Carrier, 2015).

All the above-mentioned benefits can convince any responsible teachers to regard creative writing as a necessary and indispensable part of any curriculum in a writing classroom (Clark, 2018). These benefits have been empirically supported by several studies investigating creative writing from three different strands of research.

The first set of these studies aimed at exploring the nature of creative writing by examining: (a) its correlation with other variables such as writing background and attitudes (Greenlee, 2000), the writers' identities (Zhao, 2011) or reading a literature (Barber, 2004); (b) creative writers and teachers' perception about it (Akkaya, 2014; Barbota, et al., 2012; Jamil, 2002; Mullineaux, 2017); and (c) methodology and process for evaluating creative writings (Mozaffari, 2013; Suárez, 2015).

The second set of studies is represented in a tremendous amount of work done so far to promote EFL creative writing in different educational stages. To reflect such a huge number of studies, there are more them 30 studies here in Egypt addressing this strand of research. Focusing on EFL preservice or in-service teachers, several interventions were used to enhance EFL creative writing such as a training program (Ahmed, 1994), a process-product approach (Ammar, 2001), integrating reading and writing (Abdul-Latif, 2006), scenario-based instruction (Al Hadi, 2008), predictive reading (El-Enany, 2009), prewriting tips (Khalil, 2011), inquiry-based program (Abdul-Raheem, 2015), an artbased program (Khater, 2015), a futuristic scenarios program (Al-Srour, Ali\& Al-Oweidi, 2016), a flipped-classroom (Abdel-Razik, 2019), a 
collaborative online learning strategy (Diab, 2019; El-Behery, 2013) and Ergonomics (Ghoneim\&Elghotmy, 2019).

The last set of studies explored the different effects of developing creative writing on other variables such as teachers' confidence as writers and their pedagogic methods (Murphy, 2012), teachers' emotional, psychological and social challenges (Rombough, 2016), and teachers' perceptions towards translingual creative writing pedagogy (Liao, 2018).

Reviewing all the previous studies aiming at fostering EFL creative writing skills in teacher education programs, the following point can be concluded: (a) there is a widely growing consensus that these skills should be practiced during teacher preparation, (b) no consensus can be found among these studies about what EFL creative writing means, how to foster and assess it, (c) most studies used criteria that are either too general too be easily measured or irrelevant to creativity in writing, and (d) in most studies, there are inconsistencies between the definitions adopted, intervention used and methods of assessment.

Creative writing is not simply affected by only learners' skills, but other affect aspects are also important indicators for it (Al-Srour, et al., 2016; Berk \& Ünal, 2017; Clark, 2018; Mcclenny, 2010; Piazza \& Siebert, 2008; Tok \& Kandemir, 2015; Unal, 2010). However, less attention has been paid to these internal qualities. Only recently has a resurgence of interest in affective constructs paved the way for the concept of writing dispositions to enter the educational literature (Driscoll \& Wells, 2012; Hawthorne, 2010; Piazza \& Siebert, 2008). Nowadays, it becomes certain that writing dispositionsare one of the variables required to succeed in writing (Pytash \& Li, 2014).

Piazza and Siebert (2008) consider dispositions as "a broad structure within the effective domain in which writers bring to their writing such resources as self-discipline, perseverance in the face of difficulties, tolerance of ambiguity, autonomy, willingness to take risks, motivation, self-efficacy, and interest" (p. 275). They are viewed as 
loving writing and being inclined to write (Altunkaya \& Erdem, 2017; Piazza \& Siebert, 2008). Reid (2017) considered writers' dispositions as discrete and maneuverable factors integral to their classroom learning and success.Writing dispositions are distinguished from other affective constructs such as motivation and attitudes. They are repeated and habitual pattern of behavior, rather than a one-time occurrence. They are not a static characteristic of personality; they can be nurtured and changed (Cocuk, Yelken, Ozer; 2016; Tabak \& Topuzkanamis, 2014).

Writing dispositions do not only facilitate the written product, but also help to form it (Mcclenny, 2010; Pajares \& Valiante, 1997). They enable both teachers and students to talk more truthfully and completely about what writers do (Reid, 2017). They provide insight into how to motivate and engage learners in writing (Pytash\& Li, 2014). This knowledge could be used to improve the instruction of writing as well as the product created through the writing process (Driscoll \& Wells, 2012; Hoogeveen, 2016). Improved dispositions have been shown to positively affect learners' self-efficacy and provide a strong indication of their writing ability (Hoogeveen, 2016). In addition, they play an essential role for understanding writing transfer (Driscoll \& Wells, 2012; Tremain, 2015).

Piazza and Siebert (2008) provide explicit and descriptive subcategories of writing dispositions. Mcclenny (2010) argued that these dimensions specific to all genres of writing. The three dimensions identified by Piazza and Siebert (2008) are as follows:

- Confidence: It "reflects faith or belief in an individual's ability to write and a certainty about his or her effectiveness as a writer" (p278). It is closely aligned with self-efficacy.

- Persistence: It reflects the writer's willingness to spend time writing and expend effort continuously. Good writers persevere, solve problems, revise and complete multiple drafts. They self-monitor work and voluntarily rework papers as a result of audience misunderstanding. 
- Passion: It reflects a writer's intense drive or desire to write, a strong commitment to writing, and a repeated enjoyment of writing over time. Passionate writers have a sense that writing has value for them and know what this value is. They choose to write not just for the teacher or for a grade but for a variety of purposes and for themselves and peers.

The causal relationships between college students' dispositions and their writing performance remain largely unexplored (Mcclenny, 2010; Reid, 2017). Accordingly, a few number of studies address writing dispositions and they can be classified into four different strands of research.The first strand of research either reported the development and validation of the Writing Dispositions Scale (WDS) (Piazza \& Siebert, 2008) or reported how to adapt this scale to different contexts (Işeri \& Ünal, 2010). Based on these studies, Writing Disposition Scale is found valid and reliable and it is the only research instrument known to assess writing dispositions. The second set of studies explored the nature of writing dispositions either qualitatively by analyzing students' narrations about them (Reid, 2017) or quantitatively through applying WDS to evaluate students' writing dispositions (Irseri, 2010; Mcclenny, 2010; Pytash \& Li, 2014; Tabak \& Topuzkanamis, 2014; Unal, 2010).

The third research direction examines the correlation between students' writing dispositions and other variables such as (a) reading attitudes and academic success (Baş, 2012; Baş \& Şahin, 2012), (b) gender, classroom level, mother and father's education level and income (Baş \& Şahin, 2013), (c) parents' level of education, gender, number of their reading, and the status of diary keeping (Uçgun, 2014), (d) intelligence profiles (Sengul, 2015), (e) writing transfer and learning contexts (Tremain, 2015), (f) gender, grade and attitude toward language courses (Cocuk, et al., 2016), (g) writing anxiety (Berk \& Ünal, 2017) or (h) writing legibility, speeds and styles (Memis, 2018). The last research trend addressed the effect of different interventions on developing writing dispositions such as the delivery method of teacher feedback 
(Hawthorne, 2010), creative writing activities (Avc \& Iseri, 2014; Tok \& Kandemir, 2015) or using iPad access (Hoogeveen, 2016).

Based on reviewing all the previous literature, it seems that in order to develop both the EFL creative writing skills and writing dispositions, there is a need for a comprehensive framework that provides a reasonable basis for choosing from the different wide range of strategies and activities to develop them. Salmon's (2002) e-tivities online learning model seems to provide such a framework.

In emerging internet applications, digital creative practice would prove to be an actively pursued pedagogical outcome appropriate for the students, teachers and classrooms of the $21^{\text {st }}$ century electrate society (Kovacic, Bubas \& Coric, 2012). Salmon's $(2000,2002,2004,2007)$ etivities learning model is used as an overarching framework for people interested in creating online pedagogical design of collaborative interactive learning and teaching (Wright, 2015).E-tivities are defined as "frameworks for enhancing active and participative online learning by individuals or groups" (Salmon, 2002, p.3). Salmon (2002) identifies the key features of e-tivitiesas follows:

- a small piece of information, stimulus or challenge (the 'spark');

- online activity, which includes individual participants posting a contribution;

- an interactive or participative element, such as responding to the postings of others;

- summary, feedback or critique from an e-moderator (the 'plenary');

- all the instructions to take part are available in one online message (the 'invitation')

- motivating, engaging and purposeful;

- based on interaction between learners/students/participants, mainly through written message contributions;

- designed and led by an e-moderator; 
- asynchronous (they take place over time);

- cheap and easy to run - usually through online bulletin boards, forums or conferences (p.1).

For online learning to be successful and interesting, participants need to be supported through a structured developmental process. Therefore, Salmon (2002) offers "a description of ... five-stage model, which can provide a 'scaffold' for a structured and paced program of etivities" (p.10). She stated the five-stage model provides an example of how participants can benefit from increasing skill and comfort in working, networking and learning online, and what e-moderators need to do at each stage to help them to achieve this success. The following figure (Figure 1) illustrates her model.

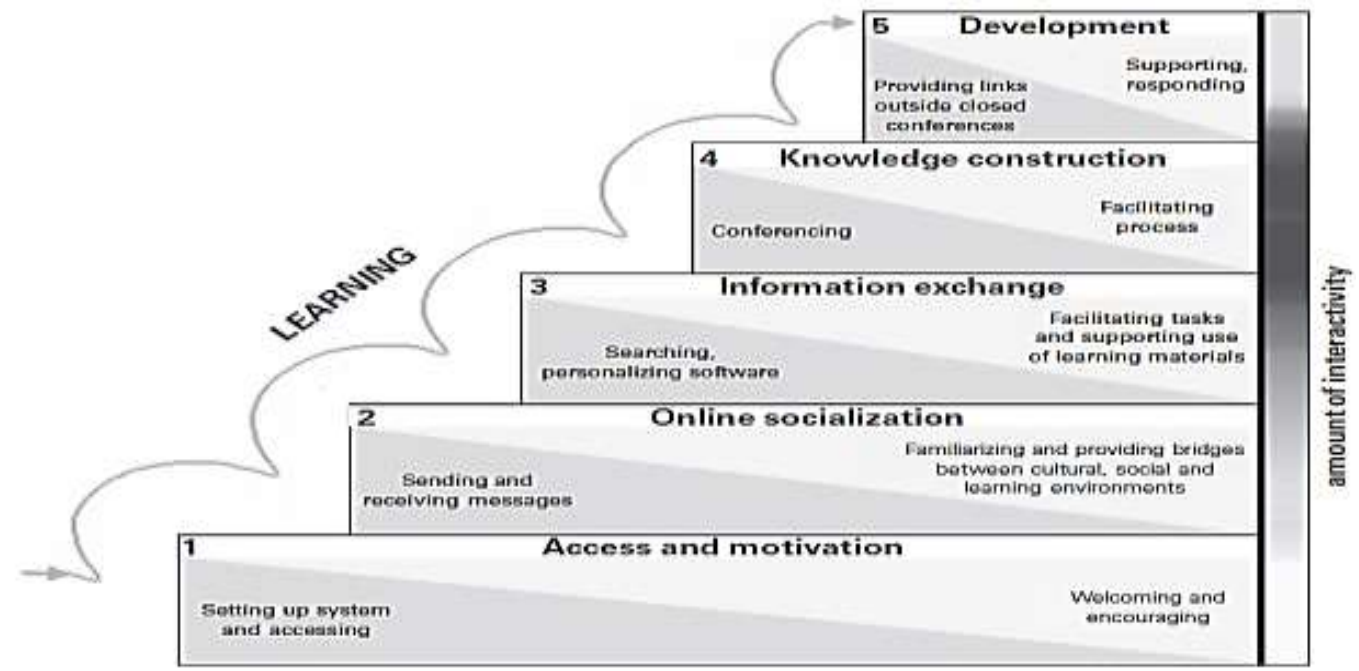

E-moderating

Technical support

Figure1: E-tivities five-stage model (adopted from Salmon (2002, p.11, 2004, p.29)

"The underlying assumption to the model is that learning involves very much more than undertaking activity on a computer". Instead it requires "an intricate and complex interaction between neural, cognitive, motivational, affective and social processes" (Salmon, 2004, p. 28). The foundations of this model include constructivism, situated learning and social learning theories (Salmon, 2002). 
Several scholars confirmed benefits gained from utilizing this model. This "model can be used in a wide range of .... learning settings, across different disciplines and may be designed to make use of many learning technologies. E-tivities are low-cost, reusable, customisable and scalable" (Armellini \& Aiyegbayo, 2009,p.1). It galvanizes students' intellectual and creative potential, and their greater linguistic/technological involvement in the course. It enables students to participate more actively in the course, to contribute and to show what they have learned and what experiences they have acquired (Kovačić, Bubaš \& Zlatović, 2008). Wright (2015) urged that this model creates a clear structured opportunity for learners to participate and interact collaboratively with the content, peers and the e-moderator. It provides the course designer a scaffold to organize course content and structure and to meet the individual online pedagogy needs of the learners.

There is very little literature that presents on the current research related to this model (Wright, 2015). Kovacic, et al. (2008) investigated e-tivities in the form of a wiki for English as a second language courses. Armellini and Aiyegbayo (2009) reported on the findings of using etivities with the focus on Carpe Diem. Kovacic, et al. (2012) aimed at presenting experiences using Web 2.0 tools in a tertiary ESP course through e-tivities. All of these studies found that e-tivities supported creative and deeper engagement with the content and fostered pedagogical change in learning design and assessment practices.

In the Arab EFL context, only four studies(to the best of the researcher's knowledge) could be reported: three of them conducted in Manama (Al-Ammar, 2011; Zourob, 2011; Gomaa, 2015) and only one in Egypt (Al-Nagar, 2016) . Al-Ammar explored its effect on developing EFL speaking skills and achievement among students at the Royal University of Girls, Zourob examined it with achievement and motivation towards EF language among secondary students, and Gomaa investigated its effects on EFL achievement and satisfaction among medical students at the Arabian gulf university in Manama. El-Nagar utilized it to foster oral proficiency skills among computer science 
students at Modern Academy for computer science and management technology in Maadi. All of them reported effective results they gained.

Based on the previous review, it can be concluded that both EFL creative writing and writing dispositions are important variables that should be developed among EFL learners. Moreover, e-tivities seems to be a promising model that needs further empirical research. Accordingly, the present study attempted to investigate the effect of using e-tivities model on developing both EFL creative writing and writing dispositions.

\section{Context of the Study}

In spite of the importance of EFL creative writing skills and writing dispositions and the need for developing them among EFL preservice teachers, there seems to be lack of these skills and dispositions among them here in Egypt. This lack was addressed by a number of studies such as Ahmed (1994), Ammar (2001), Abdul-Latif (2006), Al-Hadi, (2008), El-Enany (2009), Khalil (2011), El-Behery (2013), Abdul-Raheem (2015), Khater (2015), Al-Srour, et al. (2016), Abdel-Razik (2019), Diab (2019), and Ghoneim and Elghotmy (2019). All of these studies reported the low level of EFL creative writing skills among these students. Moreover, there is an obvious lack of interest regarding EFL writing dispositions here in Egypt which exhibits itself in the rare empirical studies addressing them.

To document the EFL preservice teachers' lack of both the EFL creative writing and writing dispositions, the researcher administered the study instruments (the EFL creative writing test designed by the researcher and Writing Disposition Scale devised by Piazza and Siebert, 2008) on a sample $[\mathrm{N}=30]$ from fourth-year EFL preservice teachers enrolled in the English section at Faculty of Education, Benha University, during the second semester of academic year 2015-2016. Using one-sample t-test, the results revealed that EFL preservice teachers did not reach the mastery level in any of them (See table 2).

Table 2 
The findings of one-sample t-test of preservice teachers' level in EFL creative writing skills and writing dispositions

\begin{tabular}{|c|c|c|c|c|c|c|c|}
\cline { 2 - 8 } & $\mathrm{N}$ & df & $\begin{array}{c}\text { Mastery } \\
\text { level }\end{array}$ & $\begin{array}{c}\text { Students' } \\
\text { mean }\end{array}$ & $\begin{array}{c}\text { Mean } \\
\text { differences }\end{array}$ & T value & $\begin{array}{c}\text { Level of } \\
\text { significance }\end{array}$ \\
\hline $\begin{array}{c}\text { EFL creative writing } \\
\text { skills }\end{array}$ & \multirow{2}{*}{30} & 79 & 145.5 & 40.10 & 105.5 & 95.55 & 0.001 \\
\cline { 1 - 6 } $\begin{array}{c}\text { EFL writing } \\
\text { dispositions }\end{array}$ & & & 372 & 155 & 217 & 46.17 & 0.001 \\
\hline
\end{tabular}

The results indicate that EFL preservice teachers' description of the setting is irrelevant or missing. They always use one type and one element of the setting in different stories. These aspectsdo not have any influence on the theme, character, and action of a story. Moreover, preservice teachersdo not use any methods of characterization, they just names them. They do not organize the events of the story. Ideas and scenes seem to be randomly arranged. They do not provide any indications of the five elements of plot. They always use one type of plot or the plot itself is missing. They do not use any technique of plotting. There is almost no opening, no conflict, no climax or no solution in their stories. They write a story with no clear narrator reflecting a weak awareness of the audience and write with unclear or no sense of tone or voice. Students' style is ineffective and does not aid in the development of the ideas of the story and does not help create proper pictures of the setting, characters and conflict.

The results of the Writing Disposition Scale revealed that they lack all the three dimensions of them: confidence, persistence and passion. All these indicators have combined to reflect a problem that needs to be addressed. The present study attempted to overcome such a problem by using E-tivities learning model.

\section{Statement of the Problem}

EFL pre-service teachers at Benha Faculty of Education seem to lack EFL creative writing skills and writing dispositions. To face such a problem, the present study is an attempt to answer the following questions: 
(a) What are the EFL creative writing skills required for the fourth-year pre-service teachers?

(b) What is the form of a program based on Salmon's e-tivities learning model aiming at developing fourth-year pre- service teachers' EFL creative writing skills and writing dispositions?

(c) What is the effectiveness of the program based on Salmon's e-tivities learning model on developing fourth-year pre- service teachers' EFL creative writing skills?

(d) What is the effectiveness of the program based on Salmon's e-tivities learning model on developing fourth-year pre-service teachers' writing dispositions?

(e) To what extent can fourth-year pre-service teachers' writing dispositions predict their EFL creative writing skills?

\section{Hypotheses of the Study}

Based on evidence gained from reviewing the related literature, the following hypotheses were formulated:

4.1. The program based on Salmon's e-tivities learning model is effective in developing EFL creative writing skills among fourth-year pre-service teachers at Faculty of Education, Benha University.

a. There is a statistically significant difference between the means of the control and experimental groups' scores on the post-application of the EFL creative writing test measuring the overall EFL creative writing skills, in favour of the experimental group.

b. There is a statistically significant difference between the means of the control and experimental groups' scores on the post-application of the EFL creative writing test measuring the "setting" dimension of EFL creative writing, in favour of the experimental group.

c. There is a statistically significant difference between the means of the control and experimental groups' scores on the post-application 
of EFL creative writing test measuring the "character" dimension of EFL creative writing, in favour of the experimental group.

d. There is a statistically significant difference between the means of the control and experimental groups' scores on the post-application of the EFL creative writing test measuring the "plot" dimension of EFL creative writing, in favour of the experimental group.

e. There is a statistically significant difference between the means of the control and experimental groups' scores on the post-application of the EFL creative writing test measuring the "theme" dimension of EFL creative writing, in favour of the experimental group.

f. There is a statistically significant difference between the means of the control and experimental groups' scores on the post-application of the EFL creative writing test measuring the "point of view" dimension of EFL creative writing, in favour of the experimental group.

g. There is a statistically significant difference between the means of the control and experimental groups' scores on the post-application of the EFL creative writing test measuring the "tone" dimension of EFL creative writing, in favour of the experimental group.

h. There is a statistically significant difference between the means of the control and experimental groups' scores on the post-application of the EFL creative writing test measuring the "style" dimension of EFL creative writing, in favour of the experimental group.

4.2. The program based on Salmon's e-tivities learning model is effective in developing writing dispositions among fourth-year pre-service teachers at Faculty of Education, Benha University.

a. There is a statistically significant difference between the means of the control and experimental groups' scores on the post-application of the writing disposition scale measuring the overall writing dispositions, in favour of the experimental group.

b. There is a statistically significant difference between the means of the control and experimental groups' scores on the post-application of the writing disposition scale measuring the "confidence" dimension of writing dispositions, in favour of the experimental one. 
c. There is a statistically significant difference between the means of the control and experimental groups' scores on the post-application of writing disposition scale measuring the "persistence" dimension of writing dispositions, in favour of the experimental group.

d. There is a statistically significant difference between the means of the control and experimental groups' scores on the post-application of the writing disposition scale measuring the "passion" dimension of writing dispositions, in favour of the experimental group.

4.3. There is a predictive correlational relationship between fourthyear pre-service teachers' writing dispositions on one hand and their EF.L creative writing skills on the other hand.

\section{Methodology of The Study}

This part provides information concerning the validity and the experimentation procedures of the present study. It provides information concerning each of the following:

- Research design of the present study.

- Participants of the study.

- Instrument construction and verification.

- Program Construction and structure.

- Experimental procedures ofinstruments and program application.

\subsection{Research Design of the Present Study}

The present study adopted the mixed research method which combines both quantitative and qualitative research methods leading to a better understanding of the research problem than either approach alone. This method provides a more comprehensive view of the problem being studied and facilitates the richness of data collected. It also expands the interpretation of the findings and increases the generalizability of the results (Creswell \& Garrett, 2008; David, Driscoll, Appiah-Yeboah, Salib \& Rupert, 2007; Johnson \& Christensen, 2004). 
The present study can be described as a partially mixed method study since qualitative and quantitative phases are included in it. It is also a sequential mixed method study because the quantitative data were collected first and then used to select participants who were subjected to the qualitative data collection and analysis. Moreover, it is a quantitative dominant status study because the study is primarily quantitative with a qualitative supportive phase. It adopts the purpose of complementarity because qualitative and quantitative results are treated as different (ElSweedy, 2012). In addition, the present study is a quasi-experimental one, the pre-post-test control-group design, in which participants were randomly assigned into two equivalent groups (the control group and the experimental group) and the independent variable is manipulated.

\subsection{Participants of the Study}

At the beginning of the first-term of the academic year 2016-2017, 103 fourth-year pre-service teachers in the English Section, Faculty of Education, Benha University were randomly assigned to the control group $[\mathrm{N}=52]$ and to the experimental group $[\mathrm{N}=51]$. Seven students were excluded from the statistical analysis for not attending the post-application of the instruments or for not attending the application of the program in a systematic way (their absence rate reached about 25\%). Thus, the study final sample comprised the control group $[\mathrm{N}=48]$ and the experimental group [ $\mathrm{N}=48]$. The sample consisted of 86 females and ten males. This was due to the few numbers of males in the actual population. Participants chosen for qualitative analysis were selected using purposeful sampling strategies in which the researcher selected "information rich" participants. Therefore, individuals $[\mathrm{N}=5]$ who represent extremes (McMillan, 2003) were selected based on their scores on the EFL creative writing teat. 
The control and experimental groups were homogeneous before conducting the experiment since they include students having nearly the same age range (21-23 years) and they are from homogenous economic and social levels. Concerning their EFL creative writing skills, the independent sample t-test ${ }^{*}$ was conducted on their scores to find whether there is any significant difference between the two groups. Table (3) summarizes these findings.

Table 3

The independent samples t-test regarding pre-service teachers' EFL creative writing skills (both groups before the experiment)

\begin{tabular}{|c|c|c|c|c|c|c|c|c|c|}
\hline \multirow{2}{*}{$\begin{array}{c}\text { Creative } \\
\text { writing } \\
\text { dimension }\end{array}$} & \multirow[t]{2}{*}{ Groups } & \multirow[t]{2}{*}{$\mathbf{N}$} & \multirow[t]{2}{*}{ Mean } & \multirow[t]{2}{*}{ S.D } & \multicolumn{2}{|c|}{$\begin{array}{c}\text { Levene's Test } \\
\text { for Equality } \\
\text { Variances } \\
\end{array}$} & \multirow[t]{2}{*}{ T-value } & \multirow[t]{2}{*}{ Df } & \multirow[t]{2}{*}{$\begin{array}{l}\text { Level of } \\
\text { significance }\end{array}$} \\
\hline & & & & & $\mathrm{F}$ & Sig. & & & \\
\hline \multirow{2}{*}{ Setting } & Control & 48 & 4.44 & 1.75 & \multirow{2}{*}{0.004} & \multirow{2}{*}{0.950} & \multirow{2}{*}{0.175} & \multirow{2}{*}{94} & 0.861 \\
\hline & Experimental & 48 & 4.50 & 1.75 & & & & & Not significant \\
\hline \multirow{2}{*}{ Character } & Control & 48 & 6.33 & 2.45 & \multirow{2}{*}{0.1} & \multirow{2}{*}{0.701} & \multirow{2}{*}{0.162} & \multirow{2}{*}{94} & 0.871 \\
\hline & Experimental & 48 & 6.42 & 2.58 & & & & & Not significant \\
\hline \multirow{2}{*}{ Plot } & Control & 48 & 11.33 & 3.99 & \multirow{2}{*}{2.087} & \multirow{2}{*}{0.152} & \multirow{2}{*}{0.781} & \multirow{2}{*}{94} & 0.437 \\
\hline & Experimental & 48 & 12.00 & 4.37 & & & & & Not significant \\
\hline \multirow{2}{*}{ Theme } & Control & 48 & 4.25 & 1.49 & \multirow{2}{*}{0.602} & \multirow{2}{*}{0.440} & \multirow{2}{*}{0.408} & \multirow{2}{*}{94} & 0.685 \\
\hline & Experimental & 48 & 4.38 & 1.51 & & & & & Not significant \\
\hline \multirow{2}{*}{$\begin{array}{c}\text { Point of } \\
\text { view }\end{array}$} & Control & 48 & 3.00 & 1.01 & \multirow{2}{*}{3.615} & \multirow{2}{*}{0.060} & \multirow{2}{*}{1.385} & \multirow{2}{*}{94} & 0.169 \\
\hline & Experimental & 48 & 3.33 & 1.33 & & & & & Not significant \\
\hline \multirow{2}{*}{ Tone } & Control & 48 & 4.44 & 1.51 & 1109 & 0295 & 0.610 & 94 & 0.543 \\
\hline & Experimental & 48 & 4.25 & 1.49 & 1.107 & & & & Not significant \\
\hline Stvle & Control & 48 & 3.75 & 1.31 & 4091 & 0.046 & 1000 & 91.690 & $\mathbf{0 . 3 2 0}$ \\
\hline Dryic & Experimental & 48 & 3.50 & 1.13 & & & & & Not significant \\
\hline overall & Control & 48 & 37.54 & 5.16 & 2816 & 0.097 & 0721 & 94 & $\mathbf{0 . 4 7 3}$ \\
\hline SNMS & Experimental & 48 & 38.38 & 6.12 & & & & & Not significant \\
\hline
\end{tabular}

Table (3) shows that there is no statistically significant difference between the means of the control group and experimental group' scores on the pre-application of the EFL creative writing test. This indicates that the two groups are homogenous in this variable before the experiment.

Concerning their writing dispositions, the independent sample ttest was conducted on their scores on writing disposition scale. Table (4) summarizes these findings.

\footnotetext{
*Data were statistically treated by the Statistical Package for Social Sciences (SPSS) software, version 11.
} 
Table 4

The independent samples t-test regarding pre-service teachers' writing dispositions (both groups before the experiment)

\begin{tabular}{|c|c|c|c|c|c|c|c|c|c|}
\hline \multirow{2}{*}{$\begin{array}{l}\text { Writing } \\
\text { disposition } \\
\text { dimension }\end{array}$} & \multirow[t]{2}{*}{ Groups } & \multirow[t]{2}{*}{$\mathbf{N}$} & \multirow[t]{2}{*}{ Mean } & \multirow[t]{2}{*}{ S.D } & \multicolumn{2}{|c|}{$\begin{array}{c}\text { Levene's Test } \\
\text { for Equality } \\
\text { Variances }\end{array}$} & \multirow[t]{2}{*}{ T-value } & \multirow[t]{2}{*}{ df } & \multirow[t]{2}{*}{$\begin{array}{c}\text { Level of } \\
\text { significance }\end{array}$} \\
\hline & & & & & $\mathrm{F}$ & Sig. & & & \\
\hline \multirow{2}{*}{ Confidence } & Control & 48 & 56.19 & 24.48 & \multirow{2}{*}{1.050} & \multirow{2}{*}{0.308} & \multirow{2}{*}{0.826} & \multirow{2}{*}{94} & \multirow{2}{*}{$\begin{array}{c}0.411 \\
\text { Not significant }\end{array}$} \\
\hline & Experimental & 48 & 52.31 & 21.36 & & & & & \\
\hline \multirow{2}{*}{ Persistence } & \begin{tabular}{|l|} 
Control \\
\end{tabular} & 48 & 53.60 & 23.70 & \multirow{2}{*}{4.778} & \multirow{2}{*}{0.031} & \multirow{2}{*}{1.203} & \multirow{2}{*}{94} & \multirow{2}{*}{$\begin{array}{c}0.232 \\
\text { Not significant }\end{array}$} \\
\hline & Experimental & 48 & 48.44 & 17.98 & & & & & \\
\hline \multirow{2}{*}{ Passion } & Control & 48 & 52.96 & 23.89 & \multirow{2}{*}{0.779} & \multirow{2}{*}{0.380} & \multirow{2}{*}{0.416} & \multirow{2}{*}{94} & \multirow{2}{*}{$\begin{array}{c}\mathbf{0 . 6 7 8} \\
\text { Not significant }\end{array}$} \\
\hline & Experimental & 48 & 51.02 & 21.68 & & & & & \\
\hline \multirow{2}{*}{$\begin{array}{c}\text { Overall } \\
\text { writing } \\
\text { dispositions }\end{array}$} & Control & 48 & 162.75 & 42.66 & \multirow{2}{*}{18.323} & \multirow{2}{*}{0.001} & \multirow{2}{*}{1.565} & \multirow{2}{*}{72.69} & \multirow{2}{*}{$\begin{array}{c}0.122 \\
\text { Not significant }\end{array}$} \\
\hline & Experimental & 48 & 151.77 & 23.27 & & & & & \\
\hline
\end{tabular}

Table (4) shows that there is no statistically significant difference between the means of the control group and experimental group' scores on the pre-application of the writing disposition scale. Accordingly, it could be said that the two groups were homogeneous before conducting the experiment.

\subsection{Instruments of the Study}

The researcher used several research tools for collecting data quantitatively and qualitatively.

\subsubsection{EFL Creative Writing Test:}

In the light of the literature review related to EFL creative writing, this test was developed in an open-ended format to allow participants to exhibit the EFL creative writing in its authentic meaning. The test, in its final form (See Appendix A), consists of two main sections. Each one asks preservice teachers to write a short story without providing them with any prompts. It just provides them with multiple instructions such as:

- While writing the short story, consider the different techniques of characterization.

- When describing the setting, try to use different sensory details. 
Each story is graded using the analytical rubric (See Appendix B) constructed by the researcher. Since the test examines 26 sub-skills, there are 26 sections in the rubric classified into seven main domains: setting, character, plot, theme, point of view, tone and style. Since each aspect can be graded from one to eight, the maximum grade that any student can get is 208 .

\subsubsection{The Analytical Rubricfor EFL Creative Writing Skills}

In the light of the literature review related to EFL creative writing, this analytic rubric was developed to analyze the participants' responses to the EFL creative writing test. This rubric provides clear, specific and detailed criteria against which each participant's short story can be analyzed and rated. The rubric is analytical, not holistic, because there are multiple rubrics corresponding to each independent dimension of creative writing.

This rubric deals with the seven main domains with 26 sub-skills of the EFL creative writing. The criteria for each sub-skill ranging from the simplest level of the skill, moving through two other levels representing the moderate levels and ending with the highest level of the skill. The four levels in each sub-skill are quantified by rating them with scores ranging from 1 to 8 respectively.

\subsubsection{Writing Disposition Scale}

The present study adopted Piazza and Siebert's (2008) Writing Disposition Scale: the only tool used in all studies of writing dispositions. The scale, (See Appendix C), consists of 93 items. These items measure three main domains of writing dispositions: confidence, persistence and passion. Each dimension is measured by 31 items. Each item is constructed to get preservice teachers' responses through a continuum that is based on the five-point Likert scale. The continuum begins with "Strongly disagree", moving through "Disagree", "Undecided", and "Agree", and ends with "Strongly agree". A value of "one" is given when the response was "Strongly disagree" and increases to "five" when the 
answer is "Strongly agree" with positive items while a value of "five" is given when the response is " Strongly disagree " and decreases to "one" when the answer is "Strongly agree" with negative items. Since the scale has 93 items, the maximum grade that any student can get is 465 .

\subsubsection{The Reliability of Study Instruments}

The EFL creative writing test and the writing dispositions were piloted on a sample of 30 fourth-year preservice teachers at the English section in Faculty of Education, Benha University, during the second term of the academic year 2015-2016. Piloting the instruments aimed at investigating the clarity of instructions and wording of the instruments and at calculating the validity and reliability of them. To determine the reliability of the instruments, the following methods were used.

\section{a. Test-Retest Method}

To use the test-retest method, the instruments were administered and re-administered to the selected participants with a two week interval. Then the Pearson Product Moment reliability coefficients of the instruments were calculated. Table (5) presents the findings of the testretest reliability coefficients of the instruments.

Table 5

The Test-Retest Reliability Coefficients of the EFL creative writing test and the writing disposition scale

\begin{tabular}{|c|c|c|c|}
\hline The Tool & $\begin{array}{c}\text { The Reliability } \\
\text { Coefficient }\end{array}$ & $\begin{array}{c}\text { NO. of } \\
\text { Subjects }\end{array}$ & $\begin{array}{c}\text { Significance } \\
\text { Level }\end{array}$ \\
\hline EFL creative writing test & $\mathbf{0 . 4 6 8}$ & $\mathbf{3 0}$ & $\mathbf{0 . 0 1}$ \\
\hline Writing disposition scale & $\mathbf{0 . 7 0 6}$ & $\mathbf{3 0}$ & $\mathbf{0 . 0 1}$ \\
\hline
\end{tabular}

Table (5) indicates that the reliability coefficients are 0.468 for the EFL creative writing test and 0.706 for the writing disposition scale which are statistically significant at the level of 0.01 . This indicates that the instruments are reliable and consistent. 


\section{b. Cronbach's Alpha Method}

Cronbach's alpha was also used to estimate the reliability of the instruments. The Alpha coefficient of the EFL creative writing test is 0.745 while it is 0.748 for the writing disposition scale. Since "it is desirable [with alpha coefficient] to have a reliability coefficient of 0.70 or higher." (Wells \& Wollack, 2003, p. 4), the values demonstrated here are acceptable revealing that the instruments are reliable and have internal consistency.

\section{c. Intra-Rater Reliability}

Directed by the nature of the EFL creative writing test and its rubric, intra-reliability was calculated to ensure the reliability of them. The researcher re-rated participants' short stories after two weeks from the first rating. Estimating the correlation between the two ratings, the intra-reliability coefficient was 0.85 that is significant at the level of 0.001 . Moreover, Stemler (2004) asserted, "values greater than 0.70 are typically acceptable for consistency estimates of inter-rater reliability" (p. 5). Therefore, this indicated that the test and the rubric are reliable.

\subsubsection{Validity of Study Instruments}

Three methods were used to ensure the validity of the instruments.

\section{a. Face Validity}

In order to determine the face validity of the instruments, they were submitted to seven jury members to verify their validity (See appendix D). In the light of their feedback, the instruments are considered to be suitable to the fourth-year EFL preservice teachers, have clear instructions and are appropriate for measuring what they are intended to measure. However, the jury suggested that few items need re-wording. Rewording these items, it could be said that the instruments have face validity. 


\section{b. Content Validity}

The instruments were developed in the light of a systematic and accurate literature review that determines the general form of the instruments and how they should be graded. Consequently, the instruments are representative of what they are intended to be measured can be interpreted as having content validity.

\section{c. Comparison of the Extreme Groups}

To estimate it, the scores of participants who scored the highest and those who scored the lowest were compared using critical ratio formula(Abou-Hatab, Othman \& Sadeq, 1999). If there is a significant difference between these extremes, the instrument is estimated as valid. The critical ratios estimated for the EFL creative writing test is 7.89 and 6.45 for the writing disposition scale. These estimates are higher than 3.29which is considered as significant at the level 0.001 (Abou-Hatab \& Sadeq, 1991). Accordingly, the instruments are valid.

\subsubsection{Instruments for Collecting Qualitative Data}

Three instruments were conducted to collect qualitative data. In the following section, a description of each instrument will be provided.

\section{a. Document Analysis}

Document analysis is a systematic qualitative procedure for reviewing or evaluating documents- both printed and electronic (computer-based and internet-transmitted) materials. It requires that data be examined and interpreted in order to elicit meaning, gain understanding and develop empirical knowledge. Document analysis is particularly applicable to qualitative intensive case studies producing rich descriptions of a single phenomenon, event, organization or program (Bowen, 2009).

EFL preservice teachers' written short stories, assignment sheets, personal, reflective and evaluative journals, materials used in teaching 
creative writing were collected and copied after each session. The researcher read these documents and sometimes asked the participants for further explanations if something significant or ambiguous emerged from these documents. Next, these written documents were used as a supplementary source for investigating the participants' EFL creative writing skills and writing dispositions.

\section{b. Focus Group Discussion}

The process of the focus group discussion begins with identifying the main aim and defining the key research objectives of the study. Then, a list of questions is prepared as guidance for each focus group discussion session. This is followed by seeking ethics clearance. "Thereafter, participant identification is perhaps the most critical step since the technique is largely based on group dynamics and synergistic relationships among participants to generate data" (Nyumba, Wilson, Derrick \& Mukherjee, 2018, p. 28). In the present study, each module is initiated and finalized by setting a list of points for focus group discussions. These sessions were videotaped and then transcribed verbatim. Accordingly, focus group discussions about the seven main dimensions of the EFL creative writing (setting, character, plot, theme, point of view, tone and style) along with their focus group discussions about the program and their confidence and passion for writing constitute the materials submitted from the focus group discussion to the qualitative analysis.

\section{c. The Researcher's Reflections and Field Notes}

Descriptive field notes provide in-depth descriptions of the setting, events, participants' interaction and activity. Reflective field notes contain the researcher's reflective commentary focusing on his/her relationship with the setting and participants, his experiences and beliefs, and his revelations and epiphanies. It also reflects on the methodological challenges and obstacles. During each session of the program, the researcher made a reflective note in which she recorded her impressions, 
observations, emerging themes and unexpected events. Moreover, she kept a regular reflective journal in which she reflected on each session.

\subsection{Program of the Study based on E-tivities learning model}

This section gives a detailed description of the study program through describing its objectives, content, teaching strategies and evaluation techniques.

\subsubsection{Determining the Objectives of the Program}

Based on reviewing the related literature, the required EFL creative writing skills were determined. The EFL creative writing skills comprise seven main dimensions (setting, character, plot, theme, point of view, tone and style) with 26 sub-skills (See Appendix E). These skills along with the three dimensions of writing dispositions are considered as the objectives of the study program.

\subsubsection{Determining the Content of the Program}

The content of the program consists of seven modules. Each module is directed toward one dimension of the EFL creative writing skills (see Appendix F). These modules are:

Module 1: The craft of the setting.

Module 2: The craft of the character.

Module 3: The craft of the plot.

Module 4: The craft of the theme.

Module 5: The craft of point of view.

Module 6: The craft of the tone.

Module 7: The craft of the style. 
In each module, there are handouts explaining this dimension in full details. Besides, there are some short stories that are assigned for reading and analyzing. Some of the analyses were also provided. Theses short stories are:

- Charlottes' Web

- From the Mixed Up Files of Mrs. Basil

- The Ugly Duckling

- The Nutcracker

- The Gift of the Magi

- The Last Leaf

- Island of the Blue Dolphins

- The Hundred Penny Box

- the Witch of Blackbird Pond

- The Billy Goats Gruff

- The Summer of the Swans
- A Wrinkle in Time,

- The Duck

- Bridge To Terabithia

- The Incredible Journey

- To Build a Fire

- Julie in Julie of the Wolves

- A Wizard of Earthsea

- Little Red Riding Hood

- Goldilocks, TheThree Little Pigs

- Double Fudge

\subsubsection{Determining the Procedures of the Program}

The procedures of the present study are directly derived from Salmon's (2000, 2002, 2004, 2007) five-stage on-line learning model. The procedures are visually represented in Figure (2).

Stage 1- Access \& Motivation:The purpose at this stage is to expose participants to the platform (not train them), and to enable them to become successful in using technology and see its benefits. E-tivities at this stage must provide participants with a gentle introduction to using the new online learning milieu and motivate them to use it (Salmon, 2002). Therefore, this stage went through the following steps:

a. Building the online creative writing learning community:

- Establishing acquaintance

- Creating a shared vision

- Setting priorities and goals

- Setting ground rules

- Organizing learning groups 
b. Accessing the online platform of the creative writing (designed by the researcher) and the different software and applications used in the program:

- The talentlms (the main platform of the program) athttps://eflcreativewriting.talentlms.com/

- How to write a short story (Google mobile app)

- Creative writing (Google mobile app)

- The novel factory (desktop app, trial version) at https://www.novel-software.com/

- Aeon Timeline 2.3.16 for Windows at https://www.aeontimeline.com/download/

- Plot generator (mobile and desktop app) at https://www.plot-generator.org.uk/

- Character generator (mobile and desktop app) athttps://www.character-generator.org.uk/

- Character writing (desktop app) at http://www.characterpro.com/characterwriter/download.html

- Tap by wattpad-interactive story community (for the dialogue section).

- The coggle (plotting tool ) at https://coggle.it/?lang=en-US

- Getting short stories from https://taletown.org/

- Writing the whole short stories (Google docs or the main template)

c. Motivating participants to contribute

- Setting up the writing centers.

- Creating the class newspaper.

- Setting up a mail station.

- Announcing a writing competition.

Stage 2 - on-line Socialization: At stage two, participants get used to being in the new online environment. E-moderator (the researcher) establishes a climate of strong enhancement of being on online group, based on respect and support for each other. In this way, intrinsic motivators will gradually emerge, and learning will be promoted. 
Therefore, at stage two, e-moderatorshould create opportunities for socialization not only into the online group, but also to understand how online contributes to learning for their topic, this course, thisdiscipline (Salmon, 2002). Therefore, all what is required at this stage is to help participants to get used to work online and navigate the different options in the apps and motivate them begin to use them. While doing this, the emoderator monitor and follow their progress.

Stage 3- Information Exchange:At stage three, participants start to appreciate the broad range of information available online and become excited about the immediate access and fast information exchange. Their learning requires two kinds of interaction: interaction with the course content and interaction with people, namely the e-moderatorand other participants. Content is usually best sent to participants as well-designed and carefully prepared by using web sites (Salmon, 2002). At this stage, not only must information be exchanged, but also cooperative tasks must be achieved. Online learners in this stage interact with the program content and with the e-moderators and/or other people.

Stage 4- Knowledge Construction: At this stage, participants begin to interact with each other in more exposed and participative ways. They formulate and write down their ideas or understanding of a topic. They read messages from other participants and respond to them. Participants' grasp of concepts and theories is enhanced through the debate and by examples advanced by other participants. At stage four, we see participants start to become online authors rather than transmitters of information (Salmon, 2002). At this stage, they discuss the different short stories they assigned to read, analyze them according to each creative writing dimension and begin to write their own short stories. They also comment and discuss each one' short story.

Stage 5- Development: At this stage, participants reflect on and discuss how they are networking and evaluate the technology and its impact on 
their learning processes. The discussion probably includes uncertainties and problems with the content and design of all aspects of the experience and an awareness of the social, ethical and technical dimensions of the experience(Salmon, 2002).E-moderators need to be prepared for this and should welcome it as evidence of real cognitive progress in their participants. He should set up exercises and online events that promote critical thinking such as commenting on each other's writing.

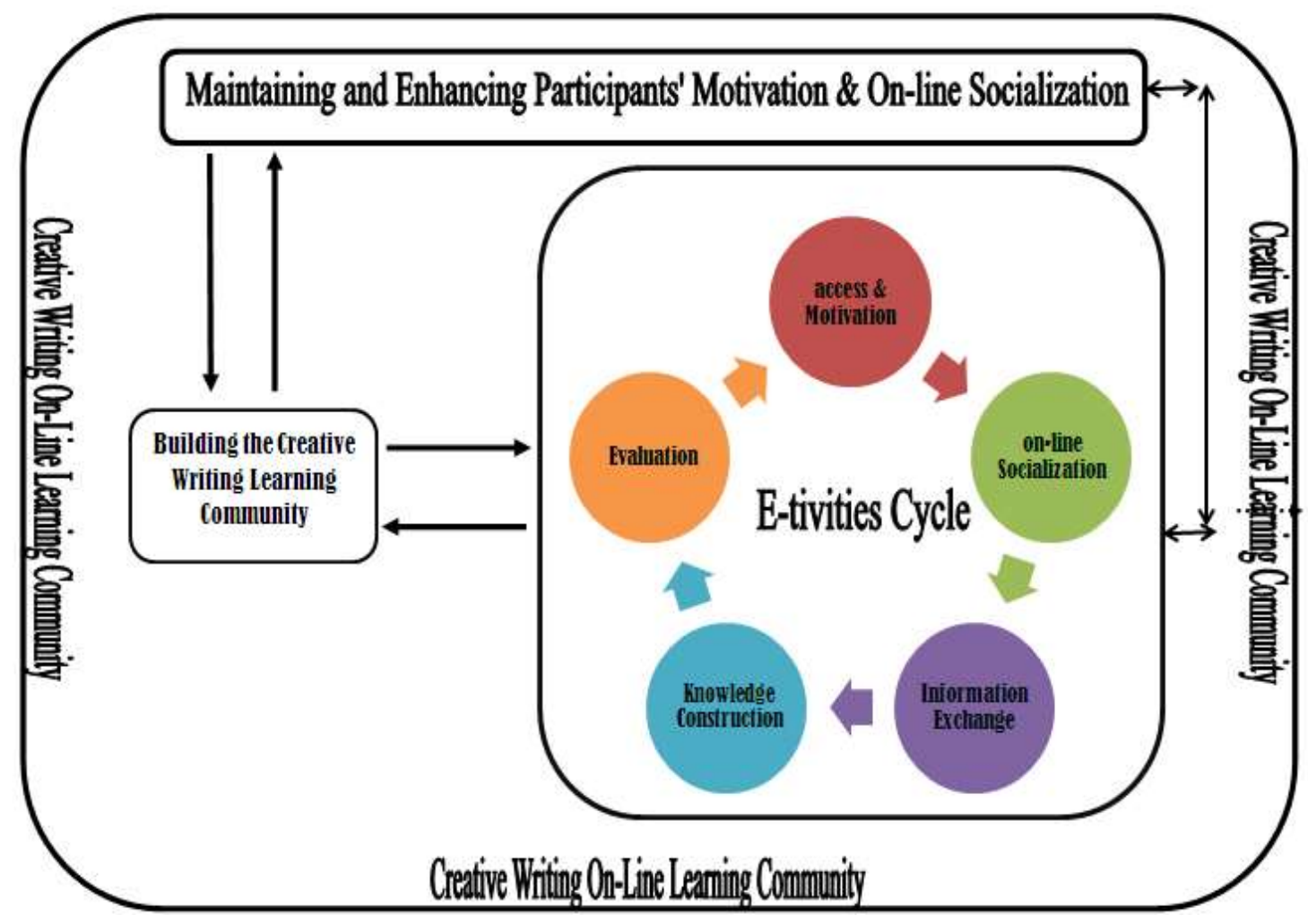

Figure 2, The Sequential Procedures of the Program

\subsubsection{Determining the Evaluation Techniques of the Program}

Several forms of evaluation are employed in the program. These forms are:

a. Diagnostic Evaluation: The aim of this form is to identify preservice teachers' initial level of both EFL creative writing and writing 
dispositions. This form is carried out throughadministering the study instruments before conducting the program.

b. The dynamic and formative evaluation: This refers to the continuous evaluation that is carried out throughout the implementation of the program. This type is represented in the continual monitoring and feedback that the educator gives to the participants in every task integrated in the program.

c. The summative form of evaluation: This form aims to get the final perspective about the fulfillment of the program objectives. It is represented in the post-application of the study instruments.

\section{Findings of the Study}

Since the data of the study were collected through two phases (quantitative and qualitative), the findings of each phase are presented separately.

\subsection{Findings of the Quantitative Analysis}

The quantitative results were dealt with and presented according to the hypotheses of the study.

\subsubsection{Quantitative Findings Concerning EFL Preservice Teachers' EFL Creative Writing Skills}

The hypothesis (1) stated, "The program based on Salmon's etivities learning model is effective in developing some EFL creative writing skills among fourth-year preservice teachers at Faculty of Education, Benha University". This research hypothesis had eight statistical sub-hypotheses dealing with the overall and seven dimensions of the creative writing skills. To examine this hypothesis, the independent sample t-test was conducted on the participants' scores on the creative writing test to compare the means of the control and experimental group's scores. Table (6) summarizes the findings of this independent t- test. 
Table 6

The independent samples t-test regarding fourth-year preservice teachers' EFL creative writing skills (overall and the seven dimensions) (control/experimental groups)

\begin{tabular}{|c|c|c|c|c|c|c|c|c|c|}
\hline \multirow{2}{*}{$\begin{array}{l}\text { Creative } \\
\text { writing } \\
\text { dimension }\end{array}$} & \multirow[t]{2}{*}{ Groups } & \multirow[t]{2}{*}{$\mathbf{N}$} & \multirow[t]{2}{*}{ Mean } & \multirow[t]{2}{*}{ SD } & \multicolumn{2}{|c|}{$\begin{array}{l}\text { Levene's Test for } \\
\text { Equality Variances }\end{array}$} & \multirow[t]{2}{*}{ T-value } & \multirow[t]{2}{*}{ Df } & \multirow{2}{*}{$\begin{array}{c}\text { Level of } \\
\text { significance }\end{array}$} \\
\hline & & & & & $\mathrm{F}$ & Sig. & & & \\
\hline \multirow{2}{*}{ Setting } & Control & 48 & 6.25 & 2.13 & \multirow{2}{*}{9.455} & \multirow{2}{*}{0.003} & \multirow{2}{*}{16.385} & \multirow{2}{*}{68.357} & \multirow{2}{*}{0.001} \\
\hline & Experimental & 48 & 17.69 & 4.34 & & & & & \\
\hline \multirow{2}{*}{ Character } & Control & 48 & 7.92 & 2.80 & \multirow{2}{*}{9.147} & \multirow{2}{*}{0.003} & \multirow{2}{*}{20.504} & \multirow{2}{*}{75.098} & \multirow{2}{*}{0.001} \\
\hline & Experimental & 48 & 24.5 & 4.86 & & & & & \\
\hline \multirow{2}{*}{ Plot } & Control & 48 & 17.67 & 5.46 & \multirow{2}{*}{2.235} & \multirow{2}{*}{0.138} & \multirow{2}{*}{21.626} & \multirow{2}{*}{94} & \multirow{2}{*}{0.001} \\
\hline & Experimental & 48 & 47.67 & 7.91 & & & & & \\
\hline \multirow{2}{*}{ Theme } & Control & 48 & 4.88 & 2.02 & \multirow{2}{*}{0.220} & \multirow{2}{*}{0.640} & \multirow{2}{*}{34.971} & \multirow{2}{*}{94} & \multirow{2}{*}{0.001} \\
\hline & Experimental & 48 & 20.81 & 2.43 & & & & & \\
\hline \multirow{2}{*}{$\begin{array}{l}\text { Point of } \\
\text { view }\end{array}$} & Control & 48 & 3.00 & 1.17 & \multirow{2}{*}{0.361} & & & & 001 \\
\hline & Experimental & 48 & 13.88 & 1.51 & & 0.549 & 39.471 & 94 & 0.001 \\
\hline & Control & 48 & 4.75 & 2.04 & & & & & 001 \\
\hline 100 & Experimental & 48 & 18.44 & 2.47 & 0.151 & 0.070 & 29.001 & 94 & 0.001 \\
\hline Stw & Control & 48 & 5.06 & 2.07 & 2060 & 0000 & 21002 & 04 & 0001 \\
\hline Niyie & Experimental & 48 & 20.13 & 2.55 & 2.300 & 0.007 & 30.00 & 37 & 0.001 \\
\hline overall & Control & 48 & 49.52 & 7.47 & 0040 & 0911 & 67540 & 04 & 0001 \\
\hline skills & Experimental & 48 & 163.10 & 8.94 & & & & & 0.001 \\
\hline
\end{tabular}

Table (6) shows that there is a statistically significant difference between the means of the control group and experimental groups' scores on the post-application of EFL creative writing test for the EFL creative writing overall skills and all their dimensions (setting, character, plot, theme, point of view, tone and style). All the t-values are significant at 0.001 level in favour of the experimental group. This indicates that the experimental group's EFL creative writing skillshave been developed. Therefore, the first main hypothesis and all its seven sub-hypotheses are confirmed. Figure (3) shows these differences in a visual form. 


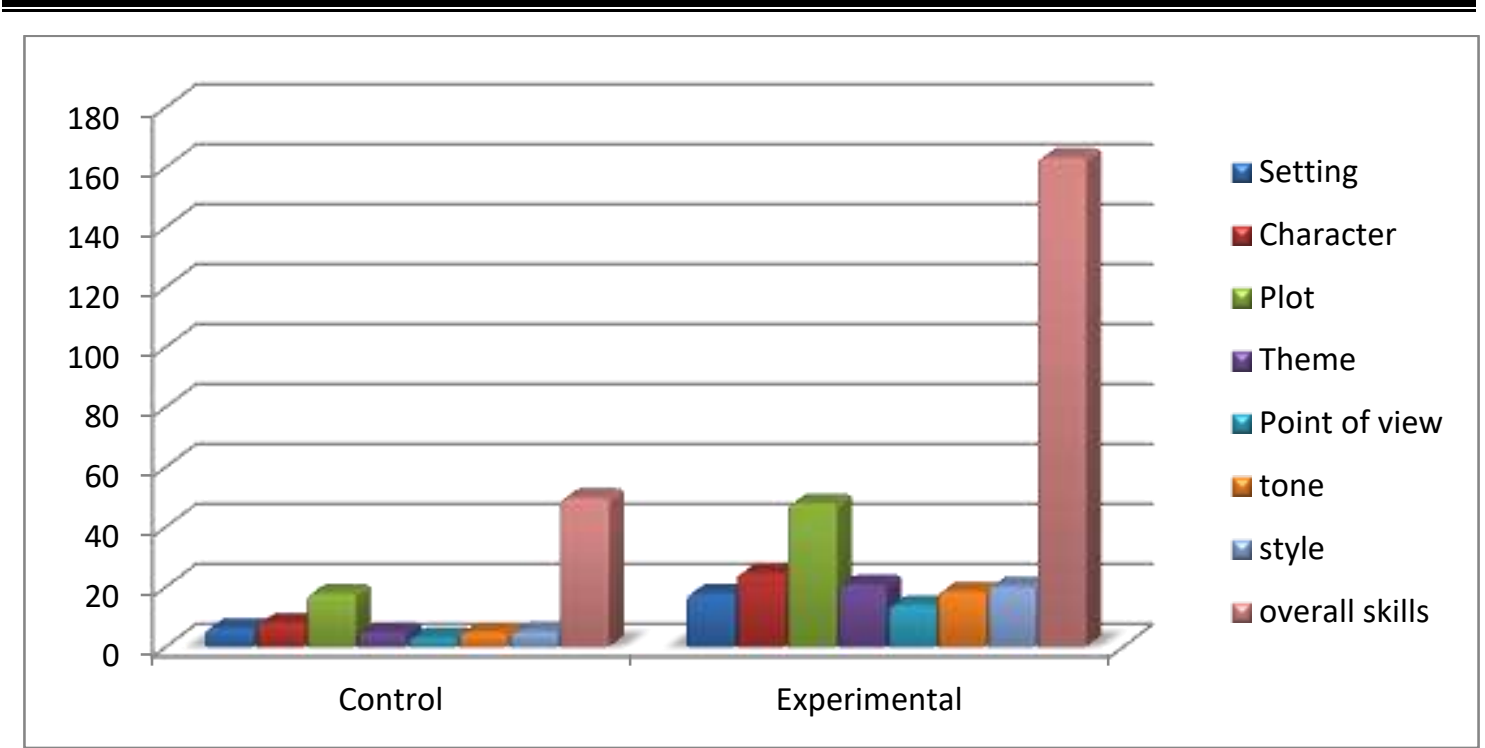

Figure2. Differences between control/experimental groups' scores concerning EFL overall creative writing skills and all of its seven dimensions

To investigate the effect size of the program based on Salmon's etivities learning model on developing EFL creative writing skills, $\eta 2$ was estimated. The value of $\eta 2$ of these skills was presented in table (7).

Table 6

$\eta 2$ value concerning the EFL overall creative writing skills and its seven dimensions

\begin{tabular}{|c|c|c|c|c|c|c|c|c|}
\cline { 2 - 9 } \multicolumn{1}{c|}{} & Setting & Character & Plot & Theme & Point of view & Tone & Style & $\begin{array}{c}\text { Overall creative } \\
\text { writing }\end{array}$ \\
\hline$\eta 2$ & 0.7971 & 0.8484 & 0.8326 & 0.9286 & 0.9431 & 0.9030 & 0.9150 & 0.9798 \\
\hline
\end{tabular}

Based on the data presented in table (7), it can be concluded that the differences or variations in the skills of creative writing which were accounted for by Salmon's e-tivities program were $97.98 \%$ for the overall creative writing skills, $79.71 \%$ for "setting", $84.84 \%$ for "character", $83.26 \%$ for "plot", $92.87 \%$ for "theme", $94.31 \%$ for "point of view", $90.30 \%$ for "tone, and $91.50 \%$ for "style". Since all these values are more than $0.138^{*}$, this indicates that the e-tivities program highly affected fourth-year EFL preservice teachers' EFL creative

*The value of w2 is interpreted by Kotrlik and Williams (2003) as follows:

A value of 0.010 shows a small, 0.059 shows a medium, and 0.138 shows a large effect size. 
writing skills and that the program has practical significance along with statistical significance in developing these skills.

\subsubsection{Quantitative Findings Concerning EFL Preservice Teachers' EFL Writing Dispositions}

The second main hypothesis stated, "The program based on Salmon's e-tivities learning model is effective in developing EFL writing dispositions among fourth-year preservice teachers at Faculty of Education, Benha University". This research hypothesis had four statistical sub-hypotheses. To examine this hypothesis, the independent sample t-test was conducted on the control and experimental group's scores on the writing disposition scale with its three dimensions. Table (8) summarizes these findings.

Table 8

The independent sample t-test regarding fourth-year preservice teachers' writing dispositions (overall and the three dimensions) (control/experimental groups)

\begin{tabular}{|c|c|c|c|c|c|c|c|c|c|}
\hline \multirow{2}{*}{$\begin{array}{c}\text { Writing } \\
\text { disposition } \\
\text { dimension }\end{array}$} & \multirow[t]{2}{*}{ Groups } & \multirow[t]{2}{*}{$\mathbf{N}$} & \multirow{2}{*}{ Mean } & \multirow[t]{2}{*}{ SD } & \multicolumn{2}{|c|}{$\begin{array}{l}\text { Levene's Test for Equality } \\
\text { Variances }\end{array}$} & \multirow{2}{*}{ T-value } & \multirow{2}{*}{ df } & \multirow{2}{*}{$\begin{array}{c}\text { Level of } \\
\text { significance }\end{array}$} \\
\hline & & & & & F & Sig. & & & \\
\hline \multirow{2}{*}{ Confidence } & Control & 48 & 72.33 & 21.53 & \multirow{2}{*}{0.912} & \multirow{2}{*}{0.342} & \multirow{2}{*}{15.244} & \multirow{2}{*}{94} & \multirow{2}{*}{0.001} \\
\hline & Experimental & 48 & 134.98 & 18.63 & & & & & \\
\hline \multirow{2}{*}{ Persistence } & Control & 48 & 69.75 & 22.61 & \multirow{2}{*}{0.038} & \multirow{2}{*}{0.845} & \multirow{2}{*}{13.364} & \multirow{2}{*}{94} & \multirow{2}{*}{0.001} \\
\hline & Experimental & 48 & 131.10 & 22.37 & & & & & \\
\hline \multirow{2}{*}{ Passion } & Control & 48 & 76.85 & 23.05 & \multirow{2}{*}{2.586} & \multirow{2}{*}{0.111} & \multirow{2}{*}{7.652} & \multirow{2}{*}{94} & \multirow{2}{*}{0.001} \\
\hline & Experimental & 48 & 118.83 & 30.22 & & & & & \\
\hline \multirow{2}{*}{$\begin{array}{c}\text { Overall writing } \\
\text { dispositions }\end{array}$} & Control & 48 & 218.94 & 83.05 & \multirow{2}{*}{1.309} & \multirow{2}{*}{0.256} & \multirow{2}{*}{19.951} & \multirow{2}{*}{94} & \multirow{2}{*}{0.001} \\
\hline & Experimental & 48 & 384.92 & 43.29 & & & & & \\
\hline
\end{tabular}

Table (8) shows that there is a statistically significant difference between the means of the control group and experimental groups' scores on the post-application of creative disposition scale for the overall writing dispositions and all three dimensions (confidence, persistence and passion). All the t-values are significant at 0.001 level in favour of the experimental group. This indicates that the experimental group's writing dispositions have been developed. Therefore, the second main 
hypothesis and all its threesub-hypotheses are confirmed. Figure (4) shows these differences in a visual form.

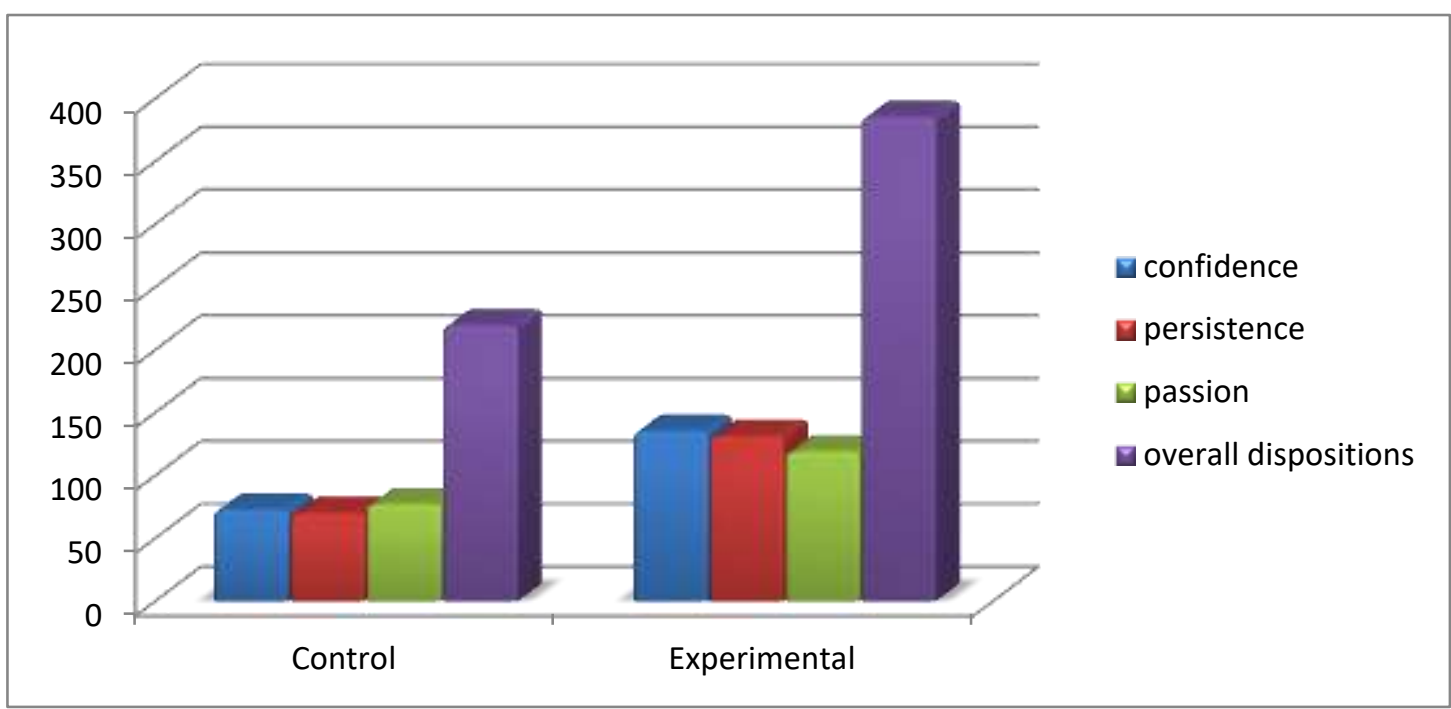

Figure 3, Differences between control/experimental groups' scores concerning overall writing dispositions and all three dimensions

To investigate the effect size of the program based on Salmon's etivities learning model on developing writing dispositions, $\eta 2$ was estimated. The value of $\eta 2$ of dimensions of the writing dispositions was presented in table (9).

Table 9

$\eta 2$ value concerning the EFL writing dispositions

\begin{tabular}{|c|c|c|c|c|}
\cline { 2 - 5 } \multicolumn{1}{c|}{} & Confidence & Persistence & Passion & Overall writing disposition \\
\hline$\eta 2$ & 0.7120 & 0.6552 & 0.3838 & 0.8090 \\
\hline
\end{tabular}

Based on the data presented in table (9), it can be concluded that the differences or variations in the writing dispositions that were accounted for by Salmon's e-tivities program were $80.90 \%$ for the overall writing dispositions, $71.20 \%$ for confidence", $65.52 \%$ for "persistence", and $38.38 \%$ for "passion. Since all these values are more than 0.138 , this indicates that the program highly affected fourth-year 
EFL preservice teachers' writing dispositions and that this program has practical significance along with statistical significance.

\subsubsection{Quantitative Findings Concerning the Relationship between EFL Creative Writing Skills and Writing Dispositions}

The third main hypothesis stated, "EFL fourth-year preservice teachers' writing dispositions can predict their EFL creative writing skills". As stated in the previous hypothesis, only one independent variable (EFL writing dispositions) is supposed to predict one dependent variable (EFL creative writing skills). Therefore, simple linear regression analysis was conducted on EFL fourth-year pre-service teachers' scores on writing disposition scale and EFL creative writing test to examine this hypothesis. Tables (10), (11), and (12) summarize these findings.

Table 10

Findings of simple linear regression analysis

\section{Coefficients}

\begin{tabular}{|c|c|c|c|c|c|c|c|c|}
\hline \multirow[b]{2}{*}{ Model } & & \multicolumn{2}{|c|}{$\begin{array}{c}\text { Unstandardized } \\
\text { Coefficients }\end{array}$} & \multirow{2}{*}{\begin{tabular}{|c|}
$\begin{array}{c}\text { Standardi } \\
\text { zed } \\
\text { Coefficien } \\
\text { ts }\end{array}$ \\
Beta \\
\end{tabular}} & \multirow[b]{2}{*}{$t$} & \multirow[b]{2}{*}{ Sig. } & \multicolumn{2}{|c|}{$95 \%$ Confidence Interval for B } \\
\hline & & B & Std. Error & & & & Lower Bound & Upper Bound \\
\hline 1 & (Constant) & 127.085 & 10.512 & & 12.090 & .000 & 105.926 & 148.243 \\
\hline & disposition & $9.358 \mathrm{E}-02$ & .027 & .453 & 3.448 & .001 & .039 & .148 \\
\hline
\end{tabular}

a. Dependent Variable: creative w riting

Table 11

Findings of simple linear regression analysis

ANOVAb

\begin{tabular}{|ll|r|r|r|r|r|}
\hline \multicolumn{1}{|l|}{} & \multicolumn{1}{|c|}{$\begin{array}{c}\text { Sum of } \\
\text { Model }\end{array}$} & Squares & df & Mean Square & \multicolumn{1}{c|}{ F } & Sig. \\
\hline 1 & Regression & 771.400 & 1 & 771.400 & 11.887 & $.001^{\mathrm{a}}$ \\
& Residual & 2985.079 & 46 & 64.893 & & \\
& Total & 3756.479 & 47 & & & \\
\hline
\end{tabular}
a. Predictors: (Constant), disposition
b. Dependent Variable: creative w riting 
Table 12

Findings of simple linear regression analysis

Model Summary ${ }^{b}$

\begin{tabular}{|l|r|r|r|r|}
\hline Model & $\mathrm{R}$ & R Square & $\begin{array}{c}\text { Adjusted } \\
\text { R Square }\end{array}$ & $\begin{array}{c}\text { Std. Error of } \\
\text { the Estimate }\end{array}$ \\
\hline 1 & $.453^{\mathrm{a}}$ & .205 & .188 & 8.0556 \\
\hline
\end{tabular}

a. Predictors: (Constant), disposition

b. Dependent Variable: creative writing

Table (10) reveals that at $\mathrm{Y}^{\wedge}=127.085$ (constant) $+9.358(\mathrm{EFL}$ writing disposition). This reveals that an increase in EFL preservice teachers' writing disposition in as much as $1 \%$ results in an increase in preservice teachers' EFL creative writing skills inasmuch as 9.358. Table (10) indicates that $t$ value $=3.448$ is significant at 0.01 level. Moreover, table (11) indicates that $\mathrm{F}=11.887$ is significant at 0.01 level. These results indicate that EFL preservice teachers' writing dispositions have an effect on their EFL creative writing skills. Table (12) indicates that the value of $R 2=0.205$ which reveals that about $20.5 \%$ of the variance of preservice teachers' EFL creative writing skills can be interpreted by their writing dispositions. Accordingly, the writing dispositions can predict preservice teachers' EFL creative writing skills to some extent $(20.5 \%)$. Therefore, the third hypothesis is confirmed.

\subsection{Findings of the Qualitative Analysis}

To get a much more detailed picture about the fourth-year preservice teachers' EFL creative writing skills, a qualitative analysis was conducted. Text or narrative data that were subjected to the qualitative analysis came from the instrument discussed previously. The qualitative analysis in the present study went through certain procedures that are derived from several researchers such as Dey (1993), GalvezMartin, Bowman and Morrison (1998), Simon (2011), and TaylorBowell and Renner (2003). Table (13) presents these procedures. 
Table 13

The qualitative Analysis Procedures

\begin{tabular}{|c|c|l||}
\hline No & Procedure & \multicolumn{1}{|c|}{ Descriptions } \\
\hline \hline 1 & Sampling & $\begin{array}{l}\text { Five fourth-year EFL preservice teachers were chosen } \\
\text { because they are the extreme and deviant cases } \\
\text { representing "information rich" participants. }\end{array}$ \\
\hline 2 & Categorizing data & $\begin{array}{l}\text { The researcher prepared all materials collected for } \\
\text { analysis and read them in details searching for themes. } \\
\text { The unit of the analysis was a conceptual unit referred } \\
\text { to as a "reflective unit" that reflects a single idea or } \\
\text { thought about the preservice teachers' EFL creative } \\
\text { writing skills. There is no specified length for this unit. }\end{array}$ \\
\hline 3 & $\begin{array}{l}\text { Identifying } \\
\text { emergent themes }\end{array}$ & $\begin{array}{l}\text { While analyzing the data, the researcher began to } \\
\text { identify the themes emerging from the raw data under } \\
\text { each heading. }\end{array}$ \\
\hline 4 & $\begin{array}{c}\text { Continuing } \\
\text { revision and } \\
\text { refinement of } \\
\text { category system }\end{array}$ & $\begin{array}{l}\text { Within each category, search for subtopics, including } \\
\text { contradictory points of view and new insights, was } \\
\text { conducted. The researcher selected appropriate quotes } \\
\text { that conveyed the core theme or essence of each } \\
\text { category. }\end{array}$ \\
\hline 5 & $\begin{array}{c}\text { Four criteria were fulfilled to enhance the } \\
\text { trustworthiness of qualitative analysis: credibility, } \\
\text { trustworthiness } \\
\text { of the findings } \\
\text { transferability, dependability, and confirmability. They } \\
\text { are achieved by using multiple data sources and } \\
\text { providing an in-depth description . }\end{array}$ \\
\hline
\end{tabular}

Going through the previous procedures, certain findings were identified. Concerning participants' skills related to the setting of the story, theydo not provide enough descriptions of the setting. They tend to begin by describing the event of the story instead of describing the setting or the characters. After the experiment, they always begin their stories by describing the setting using different details addressing as many scenes as possible. They describe what they can see, smell, hear or 
touch in the setting; their descriptions include many vivid details that make the setting come to life. They often include many elements of the setting such as the locale (the place where the story takes place) that can be a town, a city, a street or a house; time (when the story takes place), atmosphere, climate and geography. The most important aspect of their setting is that it reflects to a large scale the social, political and cultural contexts relevant to the story line. All the elements of the setting are related and relevant to the story theme and characters. Most of the time, they use integral setting not a backdrop one.

Analyzing their responses related to the characters of the story, they always introduce the characters by their names only. They do not use any other methods of characterization. Their characters always take the role of the protagonist even though the antagonist is not always clear. Their descriptions of the characters are not accurate and do not fit the type they choose. After the experiment, they begin to introduce their characters by their actions, feeling and thoughts. They use different methods of characterization such as dialogue, actions and narration. They use different types of characters, rotate their roles (e.g. the antagonist may be a main or minor character) in different stories and describe each type appropriately according to their role in the story, identity, thoughts, feelings and types.

Talking about the plot of the story, they do not organize the events of the story in which ideas and scenes seem to be randomly arranged with no sense of order.They do not provide any indications of the five elements of plot. They always use one type of plot in different stories and it is not appropriate to any elements of the story, or the plot concept is missing. They do not use any technique of plotting. There is no opening to their story. It just begins with actions and events. There is no conflict, no climax and no solution in their stories.

After the experiment, participants plot a logical series or sequence of events and character actions that relate to the central conflict and 
develop the basic ideas of the storywith clear transitions. They depict a full structure of the plot in a clear and engaging way that includes all its components (exposition, rising actions, conflict, climax, falling actions and resolution) that are readily identifiable and well-detailed.They use different types of plots in different stories that are suitable to the theme, characters, setting and conflict (e.g. man-in-a hole or man on the road). They use different appropriate techniques of plotting in different stories to attract the readers' attentions (e.g. suspense, flashback....etc). They use engaging opening lines that vividly present the story's main conflict, setting or characters and catches the reader's attention. They describe the problem or conflict facing the main character and clarify why it is a problem. Moreover, they use different types of conflict on different stories. They write an interesting climax in which the tension mounts as the story progresses. They end the story with a fulfilling, logical and suitable conclusion that solves the conflict in an interesting, authentic, logical or unexpected way. There is no loose end.

Searching for the theme of their stories, participants do not use details to highlight the theme of the story. They write a story with no theme and sometimes with no title. After the experiment, they use many descriptive details that are very appropriate and highlight the theme of the story. They write a story with a very clear, fully-developed and moral theme considering the cultural, social, religious and philosophical notions. The theme challenges readers to make value judgments. All elements of the story combine around it and thetitle sparks the readers' interest and directs them to the theme of the story.

As the fifth element of their stories, point of view, participants write a story with no clear narrator reflecting a weak awareness of the audience. They write different stories with no clear point of view. After the experiment, they write a story with clear narrator, telling the story from multiple perspectives and reflecting a strong awareness with the audience to engage them in the story.They write different stories from different eyes (e.g. innocent eye, stream of consciousness) and adopt 
different points of view (e.g. $1^{\text {st }}$ person, limited $3{ }^{\text {rd }}$ person or omniscient $3^{\text {rd }}$ person). The point of view adopted is consistent throughout the story.

Concerning the tone of their stories, participants write with unclear or no sense of tone or voice. They do not use the tone to make any changes in the story and never portray tone by any way. After the experiment, they write with a very clear and appropriate tone/voice that relate to the story and vary according the situations and characters. They use different tones in the same story to change the pace, to create the character-conflict, to fit the theme or to add pleasure. They use multiple ways to portray their tone and voice such as word choice, choice of theme or descriptions imagery.

Analyzing their style, participants use poor vocabulary and improper wording and no sentence variety. They lack sensory language. Their style is ineffective and does not aid in the development of the ideas of the story and does not help create proper pictures of the setting, characters and conflict. After the experiment, they use many rhetoric techniques that are appropriate to make meaning clearer and characters and expressions are more vivid and rich. Metaphor, personification, imagery or simile begins to appear in their stories. Participants also use very rich, precise and appealing vocabulary (sensory language) correctly, and well-varied sentences structures.

\section{Discussion \& Interpretation of the Findings of the Study}

The purpose of the present study was two-fold: (a) to develop preservice teachers' EFL creative writing skills and their writing dispositions; and (b) to examine whether preservice teachers' writing dispositions can predict their EFL creative writing skills in writing classroom. The findings of the present study are encouraging. Quantitative and qualitative analyses revealed that the program based on Salmon's e-tivities learning model had an effect on developing preservice teachers' EFL creative writing skills and writing dispositions. This can be interpreted by several factors. 
The program provided the EFL preservice teachers with intentional and constant training and practice on writing short stories through a variety of planned on-line activities coordinated with goals and objectives of developing both EFL creative writing and writing dispositions. This can be interpreted as one reason behind its success in developing them. The environment of the present study abandoned the notion of grade and set the guilt-free atmosphere. This encourages participants to contribute and interact with each other and with their educator without the feeling of being judged or assessed. This also eliminates the affective responses of anxiety, fear, loneliness and perceived helplessness which are considered as antithetical to EFL creative writing skills. This is considered to be another factor behind its success and is consistent with several researchers such as Barber (2004), Al-Hadi (2008), Daniels( 2012), Mohamed (2013), Akkaya (2014), Carrier (2015), Shalaby (2015) and Rombough (2016).

The present study provided EFL preservice teachers with a clear idea about what creative writing is and encouraged them to write different stories with different types of plots, characters and settings. Moreover, the present study followed justifiable stages and procedures based on accurate and systematic review of literature that dealt with the concept of the e-tivities learning model. This allowed a gradual transition from simple to complex; from reading different short stories, to analyzing them to writing other short stories; and from concentration on other's stories to concentration on one's own short stories.

The researcher established with the EFL preservice teachers a reciprocal relationship by considering them as being friends who are worthy of being treated as equals. She always values their input and shares relevant information. This in turn makes students feel ownership of their learning and lets them share roles flexibly. It also helps them to write freely and encourages them to engage in different discussions held in the program. 
The content used in the present study was characterized by many characteristics that may facilitate the development of EFL creative writing skills and enhance writing dispositions. The content focused on analyzing short stories, and using different online activities related to writing to motivate and stimulate their skills and dispositions. In the present study, EFL preservice teachers were given the chance to identify each element of the short story, practice different ways for writing them, create characters, stimulate conflict and problems, discover ways to resolutions, set criteria for judging, assess others' stories, justify their judgments and describe their limitations and the implications of those limitations. This reflects what Daniels (2012) refers to in claiming that the content should be meaningful and purposeful to learners.

Moreover, the present study provided EFL preservice teachers with varied tasks and activities. Using on-line platform provides preservice teachers with multiple formats for content: texts, pictures, PowerPoint presentations, videos, access to different types of short stories and different applications, each of which has many options to utilize. Discussion board, comment options and access at any time and at any place facilitate to great extent the development of EFL creative writing skills and writing dispositions. The present study also provided them with opportunity to analyze each other's stories and suggest alternatives. All these factors contribute to the success of the intervention.

Creative writing was thought to be best learned by having participants actively write creatively as opposed to a teacher instructing them on how to write creatively, or teaching them to write from reading literature, as these practices were considered detrimental to students' innate creativity (Daniels, 2012). Creative writing participants in the present study read a wide range of contemporary short stories and frequently focus on moral and social issues in them. They collaborate as they read their creative work aloud and let them then comment on each others' efforts with the teacher acting as a facilitator, not the director, of 
the dialogue. This collaborative, teacher-facilitated format was one of the main reasons for such a success.

The driving principle of social constructivist teaching and learning is for all group members, students and their instructor(s), to work in concert as a team to build a knowledge community. The present study achieved that since it was initiated by building the learning community in which participants have a shared vision about the objectives and goals of this community. This facilitates learning through positive social interaction as group members provide support and instruction to each other and a more expert member helps less knowledgeable members internalize the new information. Therefore, they master skills and dispositions wherein they replicate what they have learned and then with sufficient practice, appropriate it(Mullineaux, 2017).

In terms of the limitations of the present study and the recommendations for further studies, the small number and the nature of participants, being at the undergraduate level, limits our ability to generalize these findings to other populations. There is a need to investigate EFL creative writing and dispositions with participants with different years of experience or in different specializations. This may help in drawing a more comprehensive perspective about the relationship between EFL creative writing skills and writing dispositions.

Changing EFL preservice teachers' creative writing and dispositions needs time. The more time devoted to it, the greater potential for learning. Therefore, it seems that there is a need for extended time to develop these variables. Moreover, because of the heavy workloads the EFL preservice teachers have, they do not feel that they have a lot of time to think analytically and write creatively. They find it difficult to focus on all the requirements of how to write a short story in such a limited time. This may be one of the barriers of disposition and skill development. 
The results of the present study confirmed some of the characteristics that were advocated in the literature about EFL creative writing skills. Since the quantitative and qualitative analyses asserted that the program developed EFL preservice teachers' EFL creative writing. This confirmed what other researchers stated that creative writing can be taught and changed through instruction providing that certain conditions are given (Mohamed, 2013; Mullineaux, 2017).

Since the quantitative and qualitative analyses asserted that the EFL preservice teachers' writing dispositions can predict their EFL creative writing skills. This also confirmed that EFL teachers' dispositions may be one the most significant determiners of what is being taught, how it is being taught and what is being learned in the classroom (Al-Srour, et al., 2016; Berk \& Ünal, 2017; Clark, 2018; Mcclenny, 2010; Mohamed, 2013; Piazza \& Siebert, 2008; Tok \& Kandemir, 2015; Unal, 2010). It also emphasized that changing EFL teachers' creative writing may depend on changing their dispositions. This is asserted in previous literature in which they asserted that creative writing is an action, affected by several writers' affective aspects such as dispositions, intentions and feelings (Girardi, 2014).

\section{Conclusion}

The participants of the study have acquired the EFL creative writing skills in all its seven dimensions and writing dispositions. Therefore, Salmon's e-tivities learning model can be interpreted as effective in developing them. It can also be concluded that EFL creative writing should be purposefully and deliberately integrated in teacher education programs throughout the four years of preparation to ensure the maintenance of these skills and the transfer of their effect to other situations. 


\section{Recommendations of the present study}

In the light of the results of the study, the following recommendations are presented:

- Teacher education program should pay much attention purposefully and deliberately to EFL creative writing and writing disposition as an essential component throughout the four years of preparation to ensure their development and the transfer of their effect to other situations.

- The content of EFL creative writing course should be interesting and important from the preservice teachers' point of view. It should clarify and introduce the basic concepts underlying EFL creative writing skills in all format; fiction and non-fiction.

- Any program addressing EFL creative writing should employ different strategies and techniques that attract preservice teachers' attention and engage them in authentic tasks in a format of a workshop to enable them acquire these skills and develop appropriate dispositions.

- Forms of evaluation should be varied and progressively more demanding. They should be authentic in assessing EFL creative writing through choosing real tasks that the preservice teachers may encounter in real life.

- Teacher education program should consider getting the potentials of the on-line courses, application or resources to their programs. The potential they on-line material provides will help preservice teacher enhances different EFL skills and different modes of inquiry.

- Salmon's e-tivities leaning model is a promising model for designing and teaching on-line course. It could be adopted in different contexts and with different discipline. 


\section{Suggestions for Further Research}

The results drawn from this study refer to a need to conduct further researchers as follows:

- Replication of the study with the students at the first-year in the Faculty of Education.

- Replication of the study with the students at the higher studies in the Faculty of Education.

- Replication of the study with the students from other specializations.

- Replication of the study with the EFL preservice teachers while adopting other models rather than Salmon's e-tivities learning model.

- A comparative study of the effect of using Salmon's e-tivities learning model on both freshmen students and higher studies students.

- A follow-up study of the long-term effect of Salmon's e-tivities learning model on the same sample to figure out whether their development of EFL creative writing and writing dispositions is irreversible and transferred to other situations.

- A comparative study on the effect of using oral strategies vs. written one in developing EFL creative writing and writing dispositions.

- The effect of utilizing Salmon's e-tivities learning model on other variable such as teaching performance or any other EFL skills such as reading, speaking or listening. 


\section{Reference}

Abdel-Razik, A. R. (2019). A suggested program based on post-process writing approach using flipped classroom model to develop creative writing skills for English language major. Unpublished master thesis, Faculty of Girls for Arts, Science and Education, Ain-Shams University, Egypt.

Abdul-Latif, O. M. I. (2006). The effect of training first year English majors of the faculty of education in integrating creative reading and writing skills on their performance in these skills.Unpublished master thesis, Faculty of Education, Minia University, Egypt.

Abdul-Raheem, A. M. M. (2015). The effectiveness of an inquiry-based program in teaching poetry in developing poetic appreciation, creative reading and writing skills of faculty of education English majors. Unpublished doctoral dissertation, Faculty of Education, Minia University, Egypt.

Abou-Hatab, F., Othman, S. A. \&Sadeq, A. (1999).

فؤاد ابو حطب و سيد عثمان و امال صـادق. (999 (1). التقويم النفسى. القاهرة: مكتبـة الانجلو

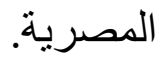

Abou-Hatab, F. \&Sadeq, A. (1991).

فؤ اد ابو حطب و آمال صادق. (1991) ). مناهج البحث و طرق التحليل الاحصائى في العلوم النفسية و التربوية و الاجتماعية. القاهرة: مكتبة الانجلو المصرية.

Ahmed, A, M. (1994).The effect of training in-service teachers of English in skill of teaching creative writing on their acquisition and use of these skills. Unpublished doctoral dissertation, Faculty of Education, Assuit University, Egypt. 
Ahmed, A. Y. (2016). The effectiveness of a suggested program based on the scaffolding strategy using blogs in developing the first-year secondary students' creative writing skills, reflective thinking, and their attitudes towards blogging. Unpublished doctoral dissertation, Faculty of Education, Sohag University, Egypt.

Akkaya, N. (2014). Elementary teachers' views on the creative writing process: An evaluation. Educational Sciences: Theory \& Practice, 14(4), 1499-1504.

Al-Ammar, A. S. (2011). The effect of using e-tivities on students speaking skill and achievement: A case on an English language course.Unpublished master thesis, Graduate School, Arabian Gulf University, Manama, Bahrain.

Al-Amro, I. A. (2012).The effect of a simulation-based instructional program on the development of students' oral communication and creative writing skills of English as a foreign language.Unpublished doctoral dissertation, Faculty of Educational and Psychological Sciences, Amman Arab University, Jordon.

Al Hadi, T. M. (2008). The use of a scenario-based programme to develop creative writing of EFL post graduate students. Studies in Curricula \& Teaching Methods, 135, 1-42.

Ali, K. S. S. (2018). Using a blended learning strategy to enhance official language prep school students' English creative writing skills.Research in Language Teaching, 4, 1-23

Ali, K. S. S. (2019). The effectiveness of a blended program on enhancing official language prep school students' English creative writing skills. Unpublished doctoral dissertation, Faculty of Education, Ain-Shams University, Egypt.

Ali, A. H. M., Salim, S. I. M. \& Mohammed, M. M. (2016).The effect of peer learning strategy on developing creative writing skills in English for secondary school students.Journal of the Educational and Social Studies, 22, 35-58. 
Ali, A. H. M., Salim, S. I. M. \& Mohammed, M. M. (2019).Using small learning communities to develop creative writing skills in English language for secondary stage students.Journal of the Educational and Social Studies, 25, 53-86.

Al-Sayed, R. K. M., Ali, M. A., Abdel-Haq, E. M, \& El-Deeb, M. A. (2017).Fostering the memoir writing skills as a creative nonfiction genre using a webquest model.Proceedings of the 1 st International Symposium of Benha Faculty of Education, Educational Technology in Education, (pp. 215-234).Benha University: Benha, Egypt.

Al-Srour, N. H., Al-Ali, S. M. \& Al-Oweidi, A. (2016). The impact of teacher training on creative writing and problem-solving using futuristic scenarios for creative problem solving and creative problem solving programs. Education, 136 (4), 461-467.

Altunkaya, H. \&Erdem, İ. (2017).Writing disposition of student convict and prisoners attending distant education secondary education school.European Journal of Education Studies, 3(7), 223-238.

Ammar, A. M. E. (2001). The effect of an integrated process-product approach to teaching writing on developing the creative writing skills of firs-year EFL majors at Sohag Faculty of Education. Unpublished doctoral dissertation, Faculty of Education, South Valley University, Egypt.

Armellini, A. \&Aiyegbayo, O. (2009).Learning design and assessment with e-tivities.British Journal of Educational Technology, 1-17.

Avc1,

A.

S.

\&Iseri,

K.

(2014).Yaraticiyazmaetkinliklerininsekizincisinifogrencilerininyaz maegilimleriveyazmakaygilarinaetkisi. [The effects of creative writing activities on the 8th grade students' writing dispositions and their writing anxiety] International Journal of Language Academy, 2(4), 152-169. 
Barber, S. (2002). The immediacy of writing: Why literature matters more to students who are creative writers. Unpublished master thesis, Faculty of Education, Simon Fraser University, Canada

Barbota, B., Tana, M., Randib, J, Santa-Donatoc, G. \&Grigorenkoa, E. (2012). Essential skills for creative writing: Integrating multiple domain-specific perspectives. Thinking Skills and Creativity, 7, 209-223.

Baş, G. (2012). Correlation between elementary students' reading attitudes and their writing dispositions.International Journal of Global Education, 1(2), 1-6.

Baş, G. \&Şahin, C. (2012).Correlation amongst reading attitudes, writing dispositions and academic success of elementary $6^{\text {th }}, 7^{\text {th }}$ and $8^{\text {th }}$ grade students in Turkish course.Turkish Studies, 7(3), 555-572.

Bas, G., \&Sahin, C. (2013).Investigating writing dispositions of elementary school students from different variables.Sakarya University Journal of Education, 3(1), 32-42.

Berk, R. R. \&Ünal, E. (2017). Comparison of writing anxiety and writing dispositions of sixth, seventh and eighth grade students.International Journal of Instruction, 10 (1), 237-254.

Bowen, G. A. (2009). Document analysis as a qualitative research method.Qualitative Research Journal, 9 (2), 27-40.

Carrier, C. S. (2015). lanode a/node an/ode: Poems and an essay on teaching digital creative writing. Unpublished doctoral dissertation, Graduate Faculty, University of Louisiana at Lafayette, USA. 
Casey-Williams, J. W. (2013). Literary know-how: Restructuring creative writing and literary studies. Unpublished doctoral dissertation, College of Arts \& Sciences, University at Albany, State University of New York, USA.

Clark, B. D. (2018). A matter of value: Creative writing strategies and their transference to composition. Unpublished master thesis, The Graduate College, Missouri State University, USA.

Cocuk, H. E., Yelken, Y. T. \& Ozer, O. (2016). The relationship between writing anxiety and writing disposition among secondary school students.Eurasian Journal of Educational Research, 63, 335-352.

Creswell, J. W. \& Garrett, A. L. (2008).The "movement" of mixed methods research and the role of educators.South African Journal of Education, 28, 321-333.

Daniels, M. A. (2012). A qualitative case study comparing a computermediated delivery system to a face-to-face mediated delivery system for teaching creative writing fiction workshops.Unpublished doctoral dissertation, School of Education, Virginia Commonwealth University, Virginia, UK.

Dey, I. (1993).Qualitative data analysis: A user-friendly guide for social scientists. London: Routledge Taylor \& Francis Group.

Diab, A. A. (2019). Using some online-collaborative learning tools (google docs \&padlet) to develop student teachers' EFL creative writing skills and writing self-efficacy.Journal of Faculty of Education(Benha), 119(3), 21-70.

Driscoll, D. L., Appiah-Yeboah, A.Salib, P. \& Rupert, D. J. (2007). Merging qualitative and quantitative data in mixed methods research: How to and why not. Ecological and Environmental Anthropology, 3 (1), 19-28. 
Driscoll, D. L. \& Wells, J. (2012). Beyond knowledge and skills: Writing transfer and the role of student dispositions. Composition Forum, 26, 1-15.

El-Behery, A. A. A. (2013).The effect of using collaborative online learning strategy on developing some creative writing skills of EFL college students. Unpublished master thesis, Faculty of Education, Minoufyia University, Egypt.

El-Enany, N. A. E. (2009).The effectiveness of a program based upon predictive reading on developing the creative writing skills of The English department students at faculties of education. Unpublished doctoral dissertation, Faculty of Education, Mansoura University, Egypt.

El-Naggar, M. A. M. (2016).The effect of an e-tivities-based program on developing English oral proficiency for modern academy students.Unpublished doctoral dissertation, Faculty of Education, Ain Shams University, Egypt

El-Sweedy, N. A. A. (2012).The effect of a suggested program on developing beliefs and teaching skills related to writing among EFL prospective teachers. Unpublished doctoral dissertation, Faculty of Education, Benha University, Egypt.

Galvez-Martin, M. E., Bowman, C. L., \& Morrison, M. A. (1998).An exploratory study of the level of reflection attained by prospective teachers.Mid-Western Educational Researcher, 11 (2), 9-18.

Ghoneim, N. M. M. \&Elghotmy, H. E. A. (2019). Utilizing ergonomics based instruction to develop college students' EFL creative writing skills. Faculty of Education Journal, Minoufyia University, 34 (2), 192-226.

Girardi, T. A. (2014). It can be acquired and learned: building a writercentered pedagogical approach to creative writing. Unpublished doctoral dissertation, School of Graduate Studies and Research, Indiana University of Pennsylvania, USA 
Gomaa, M. H. A. (2015). E-tivities design mode effect on the English language achievement and satisfaction with learning of the Arabian Gulf University medical students. Unpublished master thesis, Faculty of Post-Graduate Studies, Arabian Gulf University, Manama, Bahrain.

Greenlee, E. D. (2000). In-service and preservice teacher attitudes toward creative writing as a learning mechanism. Unpublished doctoral dissertation, College of Human Resources and Education, West Virginia University, USA

Harper, G. (2015).Creative writing and education. Bristol: Multilingual Matters

Hassan, M., Edris, A. A., Amer, A. A. (2018). A problem based learning program to enhance EFL creative writing skills of secondary stage students. Journal of Faculty of Education (Benha), 116 (3), 81-96.

Hawthorne, J. (2010). The effects of the delivery style of teacher feedback on the writing self-efficacy and dispositions of young students. Unpublished doctoral dissertation, College Of Education, The Florida State University, USA.

Hoogeveen, J. D. (2016). Changes in writing dispositions correlated with 1:1 ipad access: A quantitative ex post facto study. Unpublished doctoral dissertation, University of Phoenix, Arizona, USA.

Iseri, K. (2010). Evaluation of the writing dispositions of elementary school sixth grade students.The New Educational Review, 22(3-4), 295-305.

Işeri, K. \&Ünal, U. (2010). The adaptation of writing disposition scale into Turkish.Education and Science, 35(155), 104-116. 
Jamil, A. (2002). Creative writing: practice and theory. Al-Balqa Journal for Research \& Studies, 9 (1), 9-44.

Johnson, B., \& Christensen, L. (2004).Educational research: Quantitative, qualitative, and mixed approaches ( ${ }^{\text {nd }}$ ed.) Boston, MA: Pearson Education.

Khalil, E. R. (2011). Fostering creativity in essay writing using prewriting tips.Journal of Faculty of Arts, Bagadad University, 96, 45-71.

Khater, A. E. (2015).The impact of art-based learning program on developing English majors' creative writing.Arab Studies in Education and Psychology, 60, 387-445.

Kovacic, A., Bubas, G. \&Coric, A. (2012). Mobilising students' grammar skills through collaborative e-tivities with Web 2.0 tools.Procedia - Social and Behavioral Sciences, 34, 132 - 136

Kovačić, A., Bubaš, G., \&Zlatović, M. (2008). E-tivities with a wiki: innovative teaching of english as a foreign language. In $\mathrm{D}$. Sidelmann-Jorgensen \& M. HvidStenalt (Eds.),14th European University Information Systems (EUNIS) International Congress. Retrieved on December 15, 2010, from http://bib.irb.hr/datoteka/362544.EUNIS-2008_Awardsubmissionpaper_KovacicBubasZlatovic.pdf

Kotrlik, J. W. \& Williams, H. A. (2003). The Incorporation of effect size in information technology, learning, and performance research.Information Technology, Learning, and Performance Journal, 21 (1), 1-7.

Liao, F. (2018).Translingual creative writing pedagogy workshops: University teachers' transformations on pedagogical ideas. Unpublished doctoral dissertation, School of Graduate Studies and Research, Indiana University of Pennsylvania, USA. 
Maley, A. (2012).Creative writing for students and teachers.Humanizing Language Teaching, 14 (3), 14 pages. Retrieved on 15 March, 2019, from, https://old.hltmag.co.uk/jun12/mart01.htm

McClenny, C.S. (2010). A disposition to write: Relationships with writing performance. Unpublished doctoral dissertation, College of Education, Florida State University, USA.

McMillan, J. (2003). Educational Research: Fundamentals for the Consumer ( $4{ }^{\text {th }}$ ed.). Boston: Allyn \& Bacon.

Memiş, A. D. (2018). Examination of legibility and writing speeds of primary school students with respect to writing disposition and writing style.Universal Journal of Educational Research, 6(5), 1050-1059.

Mohamed, F. S., Abd-Alhack, E. M. \&Okasha, M. A. H. (2011).The effectiveness of the portfolio assessment approach in developing EFL creative writing among secondary school students.Educational and Psychological Studies, 70, 299-326.

Mohamed, M. F. (2013). The effect of using students` native culture on developing some creative writing and reading skills for experimental language prep school students. Journal of Reading and Literacy, 146, 55-97.

Morris, G. \&Sharplin, E. (2013). The assessment of creative writing in senior secondary English: A colloquy concerning criteria. English In Education, 47 (1), 50-65.

Mozaffari, H. (2013). An analytical rubric for assessing creativity in creative writing.Theory and Practice in Language Studies, 3 (12), 2214-2219. 
Mullineaux, K. S. (2017). More than we imagined: toward a map of beliefs and attitudes about creative writing. Unpublished doctoral dissertation, Graduate School, Northern Illinois University, USA.

Murphy, C. (2012). Practice, pedagogy and policy: The influence of teachers' creative writing practice on pedagogy in schools. School of Arts and Social Sciences, University of Northumbria, Newcastle, UK.

Nyumba, T. O., Wilson, K., Derrick , C. J. \& Mukherjee, N. (2018). The use of focus group discussion methodology: Insights from two decades of application in conversation. Methods in Ecology and Evolution, 9, 20-32.

Piazza, C. L. \& Siebert, C. F. (2008).Development and validation of a writing dispositions scale for elementary and middle school students. The Journal of Educational Research, 101(5), 275-285.

Pajares, F., \&Valiante, G. (1997). Influence of self-efficacy on elementary students' writing. The Journal of Educational Research, 90, 353-360.

Pytash, K. E. \& Li, J. (2014).The writing dispositions of youth in a juvenile detention center.The Journal of Correctional Education 65(3), 24-42.

Ramet, A. (2007). Creative writing: How to unlock your imagination, develop your writing skills, and get published ( ${ }^{\text {th }}$ Ed.).Oxford: How to content.

Reid, E. S. (2017). Defining dispositions: Mapping student attitudes and strategies in college composition. In P. Portonova, J. M. Riffenberg\& D. Roen (eds.), Contemporary Perspectives on Cognition and Writing (pp. 291-312). Colorado: WAC Clearinghouse Press. 
Rombough, K. (2016). The "write" way: creative writing as a schoolbased approach to treat childhood and adolescent anxiety.Unpublished master thesis, Faculty of Education, Queen's University, Ontario, Canada.

Salmon, G. (2000).E-moderating: The key to teaching and learning online. London: Taylor \& Francis.

Salmon, G. (2002).E-tivities: The key to active online learning. London: Taylor \& Francis.

Salmon, G. (2004).E-moderating: The key to teaching and learning online $\left(2^{\text {nd }} \mathrm{ed}.\right)$. London: Taylor \& Francis.

Salmon, G. (2007).80:20 for E-moderators.CMS-JOURNAL, 29, 39-43.

Sengul, M. (2015).The relationship between writing dispositions and intelligence domains of gifted students.International Journal of Higher Education, 4(4), 207-215.

Shalaby, N. M. K. (2015). Using the storytelling approach based on visualization in developing creative writing skills of EFL language primary school pupils.Unpublished master thesis, Faculty of Education, Damietta University, Egypt.

Simon, M. K. (2011). Analysis of qualitative data. In M. K. Simon (Ed.), Dissertation and scholarly research: Recipes for success. Seattle, WA, Dissertation Success, LLC.

Stemler, S. E. (2004). A comparison of consensus, consistency, and measurement approaches to estimating inter-rater reliability. Practical Assessment, Research \& Evaluation, 9 (4), 1-11.

Suarez, S.D. (2015). Evaluating creative writing: The criterion behind short stories' assessment.Unpublished doctoral dissertation, UniversitatAutonoma de Barcelona, Spain. 
Tabak, G. \&Topuzkanamis, E. (2014).An analysis of writing dispositions of $6^{\text {th }}$ grade students in terms of different variables.Mevlana International Journal of Education (MIJE), 4(2), 1-11.

Taylor-Powell, E. \& Renner, M. (2003).Analyzing qualitative data.Wisconsin: WisconsinUniversity.

Thaker, S. (1995).A study of the effect of an encouraging environment and appropriate training on creative writing ability of students.Unpublished doctoral dissertation, Department of Education, Sardar Patel University, India.

Tok, S. \&Kandemir, A. (2015).Effects of creative writing activities on students' achievement in writing, writing dispositions and attitude to English.Procedia - Social and Behavioral Sciences, $174,1635-1642$.

Tremain, L. D. (2015). "I feel confident most of the time": A study of the relationships between writing transfer, dispositions toward learning and writing, and perceptions of classroom contexts. Unpublished doctoral dissertation, University Of California, USA.

Tung, C. K. (2015). Assessment of creative writing: The case of Singapore secondary Chinese language curriculum. Universal Journal of Educational Research, 3(10), 655-662.

Uçgun, D. (2014). Analysis of writing dispositions of sixth grade students.Education and Science, 39(175), 227-238.

Ünal, E. (2010). An analysis of the writing disposition of fourth and fifth grade elementary school pupils.Education, 131(2), 319-330. 
Wells, G. S. \&Wollack, J. A. (2003).An Instructor's guide to understanding test reliability (A technical report). Wisconsin: The Office of Testing \& Evaluation Services, University of Wisconsin. Retrieved on September 13, 2005, from http://testing.wisc.edu/Reliability.pdf

Wright, P. (2015). Comparing e-tivities, E-moderation and the five stage model to the community of inquiry model for online learning design.The Online Journal of Distance Education and e-Learning, 3 (2), 17-30.

Zhao, Y. (2011). L2 creative writers: Identities and writing processes. Unpublished master thesis,Centre for Applied Linguistics, University of Warwick, UK.

Zourob, A. A. M. (2011). The impact of using e-tivities in blended learning on students' achievement and motivation towards learning English language course.Unpublished Master thesis, Faculty of Post-Graduate Studies, Arabian Gulf University, Manama, Bahrain. 